\title{
Helicobacter pylori and gastric cancer: a lysosomal protease perspective
}

\author{
Surinder M. Soond ${ }^{1,2}$ (D) Andrey A. Zamyatnin $\mathrm{Jr}^{1,2,3,4}$
}

Received: 5 October 2021 / Accepted: 1 December 2021 / Published online: 16 December 2021

(c) The Author(s) 2021

\begin{abstract}
The intimate involvement of pathogens with the heightened risk for developing certain cancers is an area of research that has captured a great deal of attention over the last 10 years. One firmly established paradigm that highlights this aspect of disease progression is in the instance of Helicobacter pylori infection and the contribution it makes in elevating the risk for developing gastric cancer. Whilst the molecular mechanisms that pinpoint the contribution that this microorganism inflicts towards host cells during gastric cancer initiation have come into greater focus, another picture that has also emerged is one that implicates the host's immune system, and the chronic inflammation that can arise therefrom, as being a central contributory factor in disease progression. Consequently, when taken with the underlying role that the extracellular matrix plays in the development of most cancers, and how this dynamic can be modulated by proteases expressed from the tumor or inflammatory cells, a complex and detailed relationship shared between the individual cellular components and their surroundings is coming into focus. In this review article, we draw attention to the emerging role played by the cathepsin proteases in modulating the stage-specific progression of Helicobacter pylori-initiated gastric cancer and the underlying immune response, while highlighting the therapeutic significance of this dynamic and how it may be amenable for novel intervention strategies within a basic research or clinical setting.
\end{abstract}

Keywords Helicobacter pylori $\cdot$ Gastric cancer $\cdot$ Cathepsins $\cdot$ Inflammation $\cdot$ Extracellular matrix

$\begin{array}{ll}\text { Abbreviations } \\ \text { APC } & \text { Antigen-presenting cells } \\ \text { BMDC } & \text { Bone marrow-derived cells } \\ \text { BMDSC } & \text { Bone marrow-derived stem/suppressor cells } \\ \text { CAF } & \text { Cancer-associated fibroblast cells } \\ \text { CagA } & \text { Cytotoxicity-associated gene A protein } \\ \text { CTLS } & \text { Cytotoxic T cells } \\ \text { ECM } & \text { Extracellular matrix }\end{array}$

Surinder M. Soond

s.soond@surrey.ac.uk

1 Department of Immunology, Faculty of Health and Medical Sciences, University of Surrey, Guildford GU2 7XH, UK

2 Institute of Molecular Medicine, Sechenov First Moscow State Medical University, Trubetskaya str. 8-2, Moscow 119991, Russian Federation

3 Department of Biotechnology, Sirius University of Science and Technology, 1 Olympic Ave, Sochi 354340, Russian Federation

4 Belozersky Institute of Physico-Chemical Biology, Lomonosov Moscow State University, Moscow 119992, Russian Federation
EMT Epithelial-mesenchymal transition

GC Gastric cancer

MALT Mucosa-associated lymphoid tissue

MAPK Mitogen-activated protein kinases

MMP Matrix metalloprotease proteins

MOMP Mitochondrial outer membrane permeabilization

NK Natural killer cells

PAMP Pathogen-associated molecular pattern proteins

ROS Reactive oxygen species

RNS Reactive nitrogenous species

TAF Tumor-associated fibroblast cells

TAM Tumor-associated macrophage cells

TIN Tumor-infiltrating neutrophil cells

TLR Toll-like receptor proteins

TME Tumor microenvironment

VacA Vacuolating cytotoxic A protein

WHO World Health Organization 


\section{Introduction}

According to 2018 World Health Organization (WHO) and Global Burden of Cancer (GLOBOCAN) estimates, gastric cancer (GC) is the third and fourth leading cause of annual cancer mortality in respective males and females, from the total estimate of 9.6 million cancer deaths worldwide [1]. Generally, GC arises from the complex interplay between a number of important factors arising from host genetics [2], the environment, lifestyle factors and microbial factors [3]. From the latter, the gut microbiome takes on great significance as it represents the largest and the most diverse microbial ecosystem in the human body and serves to generally support the host's mucosal immune response to eliminate pathogens [4]. The importance of inflammation in response to pathogens and the specific role it plays in cancer progression had been noted as being of key importance, as reported by Rudolf Virchow as far back as 1863, where the origins of certain cancers were positively correlated with sites of persistent inflammation [5]. Subsequently, microbes or microbiota and their inflammatory effects have been increasingly recognized in as much as $20 \%$ of all cancers [6] and more specifically in colorectal cancer [7, 8], prostate cancer [9], colon cancer [10] and gallbladder cancer [11].

Of significant relevance is the Gram-negative bacterium Helicobacter pylori (H. pylori), which has been reported to asymptomatically colonize over $50 \%$ of the world's population and can become established within the gastric lining of individuals early on in life [12]. As a likely precursor for the carcinogenesis of the stomach, it has consequently been categorized as a Class 1 carcinogen, by the WHO [13]. While $10 \%$ of $H$. pylori infections are associated with peptic ulcer disease, around 1-3\% if those infected will progress to GC with an estimated survival rate of under 5 years [14]. Moreover, a further $0.1 \%$ will develop mucosa-associated lymphoid tissue (MALT) lymphoma [15]. The development of this scientific paradigm of key importance was indeed grounded upon the milestone discovery of the Gram-negative bacteria $H$. pylori as being the infectious agent that caused chronic gastritis [16-19], atrophic gastritis, intestinal metaplasia, dysplasia and carcinoma of the stomach, thus contributing to the histopathological Correa model for gastric carcinogenesis $[3,20]$.

Mechanistically, the virulent actions of the $H$. pylori cytotoxicity-associated gene A ( CagA) and vacuolating cytotoxic A (VacA) proteins on gastric mucosa cells can instigate a complex array of biological effects ranging from the production of pro-inflammatory cytokines and the recruitment of immune cells to the site of infection, to triggering gastric epithelial cell survival responses $[15$,
20]. To ensure its survival and disease progression, $H$. pylori can suppress the activities of phagocytic cells and T-cell functions during infection [21], while catalyzing the formation of urea as a way of assuring its own survival under the harsh low $\mathrm{pH}$ conditions of the stomach [21]. Additionally, the by-products of $H$. pylori metabolism can be significantly destructive to the host's epithelial cells and contribute to the carcinogenic effects of $H$. pylori infection.

At the cellular and molecular levels, of central importance is the extracellular matrix (ECM) and the dynamic nature of which permits tumor-associated inflammatory cells to become established, while also directly contributing to angiogenesis of the tumor and the mobilization of tumor cells [22-24]. Central to ECM modulation are the matrix metalloproteases (MMPs) and the cathepsin proteases, which over the last 10 years have gained importance based on the contribution of their expression during tumor development and metastasis [25-27]. Consequently, of importance is the question of how such proteases can holistically modulate the ECM, modulate the inflammatory- and adaptive-immune responses directed by neutrophils, macrophages, dendritic cells or cytotoxic T cells (CTLs), and to favor tumor cell growth [28]. Collectively, as central regulators of a complex series of biological effects that are central to GC progression, the cathepsin proteases, do have exceptional potential to be therapeutically targeted, with a number of agents currently being evaluated for therapeutic purposes [29, 30].

In this article, we focus on the relationship that has developed between $H$. pylori and GC progression, through building on the importance of pathogen-induced inflammation and the immune response as a central theme, whilst detailing additional emerging molecular mechanisms of significance that are responsible for this relationship to take effect, namely through the actions of the cathepsin proteases toward the ECM (Fig. 1). By unveiling the interplay of these molecular mechanisms, we identify key axes of regulation, which may hold potential in being therapeutically targeted, either at the basic research level or within the clinic.

\section{Helicobacter pylori infection and gastric cancer progression}

Helicobacter pylori infection can change the composition of the gastric microbiota by raising the $\mathrm{pH}$, allowing the creation of a niche for bacterial colonization, and which favors consistent and prolonged $H$. pylori infection. Consequently, gastritis, gastric ulcer, atrophy and gastric cancer can progressively develop, as depicted in the proposed Correa model for GC development in Fig. 1 [20]. Therapeutically, the eradication of $H$. pylori can prevent the onset of $\mathrm{GC}$ as seen from treating infected patients suffering from 


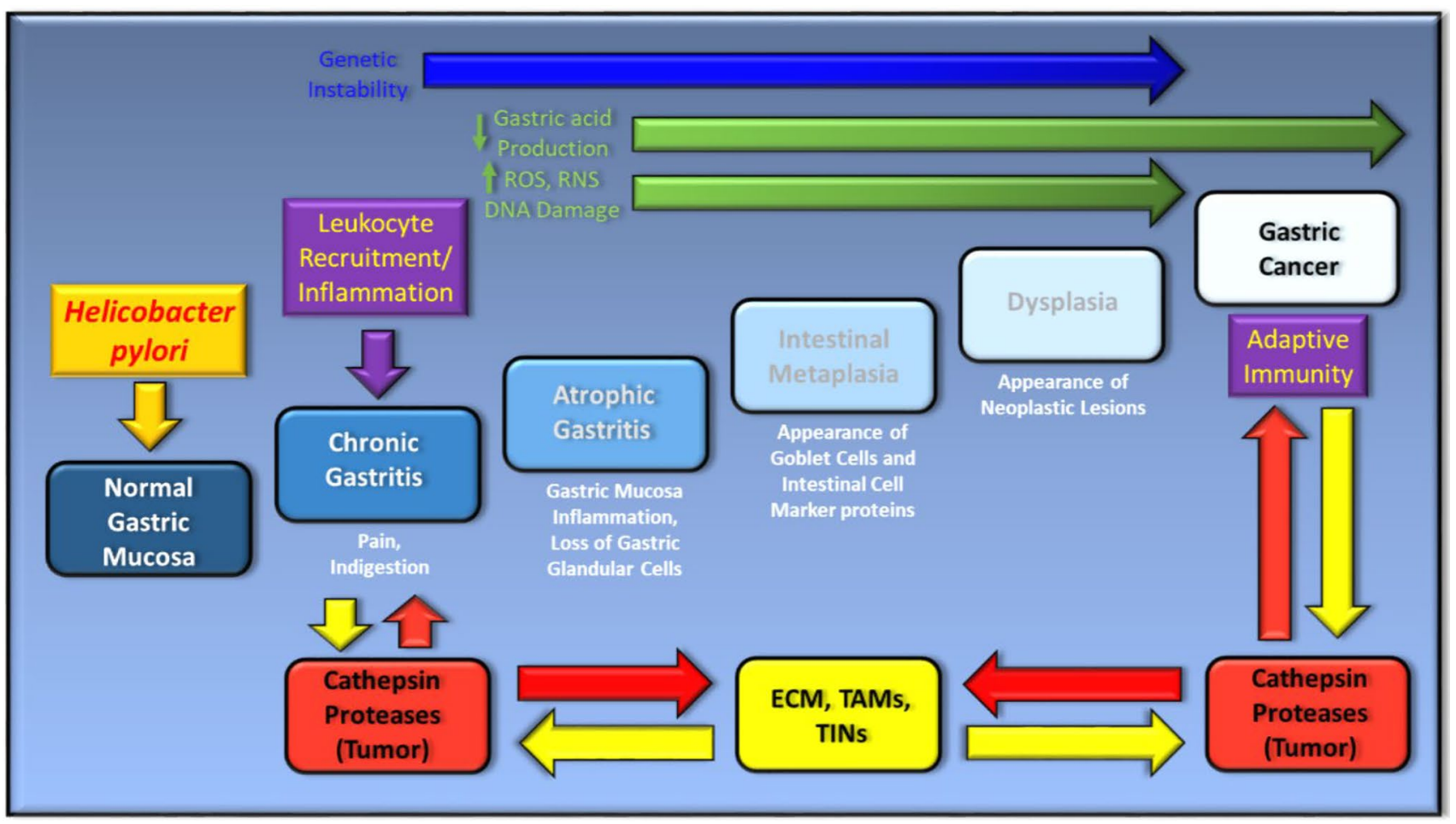

Fig. 1 Helicobacter pylori infection and key contributing factors in the progression of gastric cancer. H. Pylori infection of the gastric mucosa induces chronic inflammation (orange arrow), which can drive the development of gastric cancer through the interplay of genetic factors (blue arrows), key biochemical factors (green arrows) and extracellular or cellular factors from the immune system (yellow arrows). The cathepsin proteases (red boxes) and their regulatory input into modulating the extracellular matrix (ECM), tumor-associated macrophages (TAMs), tumor-infiltrating neutrophils (TINs), the innate and adaptive immune response are highlighted (red arrows). Tumor-derived cathepsin proteases can also be modulated by components derived from the ECM, TAMs, TINs and the innate or adaptive immune response (yellow arrows)

pre-cancerous lesions in the host [37]. Approximately, 100\% of East Asian and 70\% of Western H. pylori strains encode the $C a g A$ gene [34, 38], which along with the VacA protein can be shed from the bacteria in response to bacterial stress in the form of bacterial outer membrane vesicles (OMVs) $[39,40]$. Once inside the cell, the CagA protein can undergo phosphorylation by Src and Abl kinases [41, 42] and activate the SHP2 phosphatase, the interplay of which can collectively contribute to cellular morphological changes, such as enhanced cellular elongation and cell scattering [35, 42, 43]. Here, mitogen-activated protein kinase activation (MAPK) is a contributing factor [38], as is the modulation of epithelial cell junction integrity, which alters epithelial permeability and cellular polarity [38]. Moreover, through the activation of MAPKs and anti-apoptotic MCL1 protein expression, intracellular CagA can counteract VacA-mediated stressinduced apoptosis of mammalian cells [44], through dampening VacA-enhanced endoplasmic reticulum (ER) stressinduced C/EBP homologous transcription factor protein (CHOP) expression (Fig. 2) [45]. An additional and alternative mechanism proposed for VacA-mediated apoptosis regulation occurs through the modulation of mitochondrial 


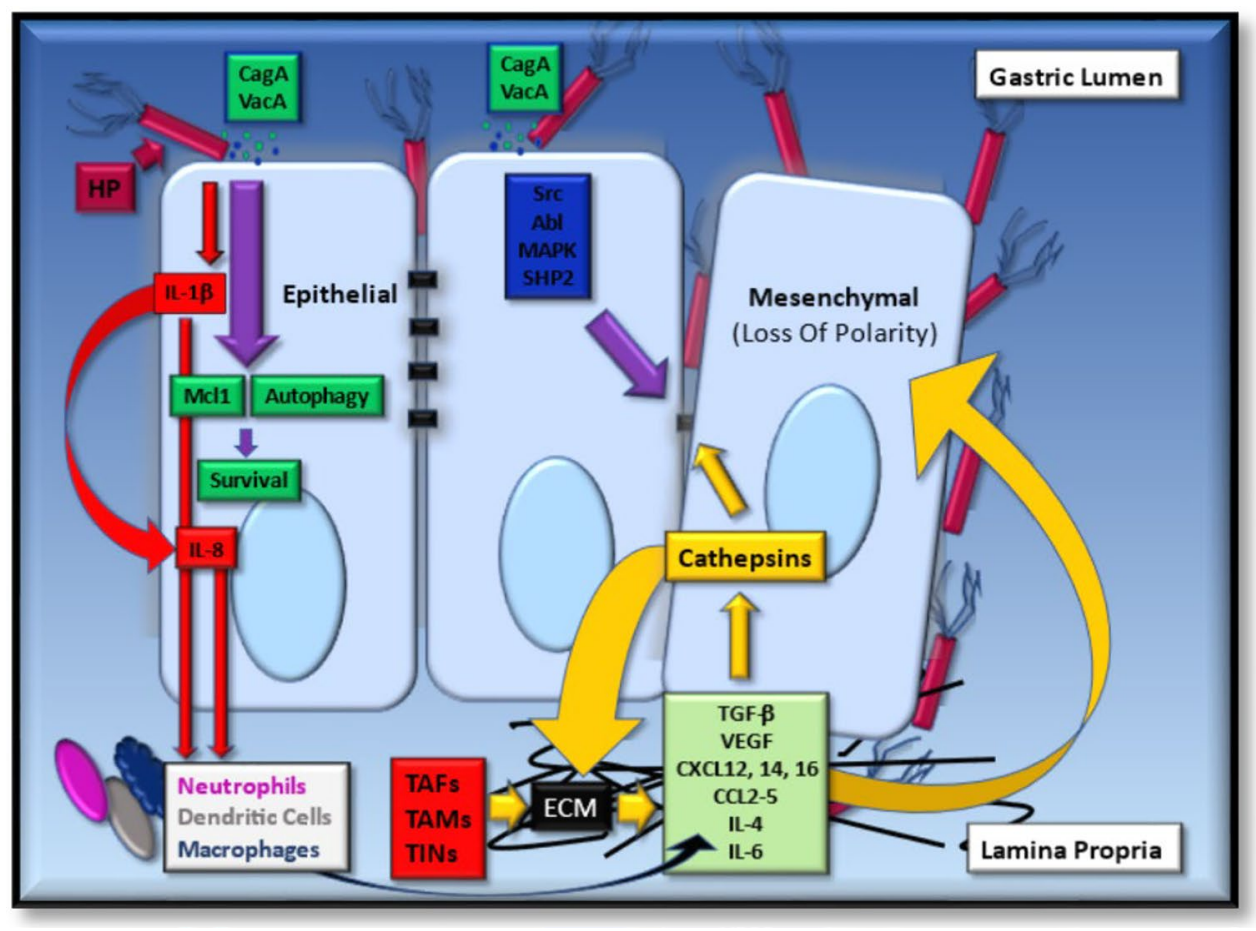

Fig. 2 The localized inflammatory response upon the infection of gastric epithelial cells by $H$. pylori (HP). Gastric epithelial responses to HP infection through the actions of CagA and VacA result in activation of cell survival through Mcl-1 protein induction and autophagy regulation. IL1 $\beta$ and IL-8 expression (red arrows) is also upregulated which induce the influx of inflammatory cells. Persistent inflammation upregulates the expression of a number of cytokines and chemokines (pale green box), which can contribute to epithelial gastric cancer cells differentiating to mesenchymal cells. Such signal-

outer membrane permeabilization (MOMP), and its activation of the intrinsic arm of the apoptosis pathway [46]. VacA can also induce autophagy and CagA degradation through ROS expression and Akt kinase activation [47]. However, persistent exposure of epithelial cells to VacA can deregulate autophagy through disarming autophagosomes, promoting cell survival and accumulating ROS expression, thus potentiating localized inflammation and cellular carcinogenesis $[48,49]$.

\section{Helicobacter pylori, inflammation and the immune response}

The chronic gastritis phase of $H$. pylori infection takes on additional seriousness from the perspective of recruiting immune cells, which are a significant source of pro-inflammatory cytokines or ROS and RNS species, with very distinct mechanistic effects during GC development. Initially, neutrophils are directed to the gastric mucosa in response to the actions of CagA-mediated activation of transcription ing cues can also enhance the expression and secretion of cathepsin proteases (yellow box and arrows), which can act on modifying the extracellular matrix (ECM, black box), along with cathepsins derived from tumor-associated fibroblasts (TAFs), -macrophages (TAMs) and tumor-infiltrating neutrophils (TINs). As contributing mechanisms to gastric cancer progression, cathepsins can also target the cleavage of cell-cell junctions (black tabs), the expression of which can also be negatively modulated upon the activation of signal transduction pathway intermediates by CagA and VacA (blue box)

factor NF- $\mathrm{BB}$, which can induce IL- $1 \beta$ expression and secretion from gastric epithelial cells [50, 51]. Subsequently, macrophages and dendritic cells are recruited as a consequence of enhanced permeability of the gastric mucosa $[52,53]$. Contributing to this effect is the IL- $1 \beta$-dependent expression of IL-8, which, through a positive feedback loop and drives enhanced gastric IL- $1 \beta$ expression, culminating in enhanced mucosal inflammation [54] and low gastric acid output, which are necessary precursor steps for gastric atrophy [55], hyperplasia and GC [20], even in the absence of an adaptive immune system [56]. Here, of specific importance are the pathogen recognition receptors, such as the Toll-like receptors (TLRs) and nucleotide-binding oligomerization domain (NOD)-like receptors (NLRs) that are found on the surface of epithelial, macrophage, neutrophil and dendritic cells [57]. Their occupation, by unique bacterial pathogenassociated molecular pattern proteins (PAMPs), can generally signal through the MyD88 and TRIF protein intermediates that activate NF- $\mathrm{KB}, \mathrm{AP}-1$ and IRF3 [58], which mediate the upregulated expression of the cytokines IL-8, TNF- $\alpha$, IL- $1 \beta$, IL-6, IL-10 and IFN- $\gamma$ [59]. Moreover, NLRs 
and leucine-rich repeat-containing proteins accessorize TLR signaling to form the inflammasome [60], which is fundamental to IL- $\beta$ and IL-18 cytokine maturation. Briefly, $\mathrm{NF}-\kappa \mathrm{B}$ activation can upregulate pro-IL- $1 \beta$, pro-IL-18 and NLRP3 protein expression, the latter of which permits the recruitment of pro-caspase-1 using the adaptor protein ASC. Through this PAMP/TLR/NLR complex, caspase-1 can become activated and cleaves IL- $1 \beta$ and IL-18 precursors giving rise to their mature forms, which are secreted in a gasdermin-D-dependent manner [61]. NRLP3 inflammasome-containing cells can subsequently die by pyroptosis, thus restricting the growth of intracellular bacteria [61]. Interestingly, while this may be one way in which the mucosal epithelial layer is breached, another is by the epigenetic loss of e-cadherin expression, through the methylation of its gene promoter, as seen in the presence of IL-1 $\beta$ and CagA stimulation of cancer cells (Fig. 2) [62, 63].

From an immunity perspective, a key mammalian defense mechanism for bacterial clearance is phagocytosis. H. pylori encodes the sialic acid-binding adhesion (SabA) and blood group antigen-binding adhesion (BabA) proteins, which permit $H$. pylori binding to epithelial cells [64]. SabA can also bind human neutrophil receptors, and in doing so induce phagocytosis and ROS production [34]. Following phagocytosis, phagosomes may also fail to mature through the activity of VacA, and instead resemble early endosomes that exhibit deficient lysosome fusion abilities particularly for highly virulent type I strains of $H$. pylori infection in professional APCs [65]. Nevertheless, following phagocytosis, $H$. pylori can express arginase 2 , which reduces NO or $\mathrm{O}_{2}{ }^{-}$radicals and contributes to $H$. pylori survival $[66,67]$. This can also be achieved through the bacterial expression of SOD, catalase and peroxiredoxins [67]. Collectively, such mechanisms contribute to $H$. pylori survival. The subsequent formation of ROS can activate caspase-1, thus enhancing inflammasome activity and pro-inflammatory cytokine secretion [68].

In summary, epithelial cells can respond to $H$. pylori infections upon TLR receptor occupation, while inflowing immune cells respond by TLR occupation and phagocytosis. The production and secretion of pro-inflammatory cytokines mediate inflammation during chronic gastritis and atrophic gastritis during GC progression, for which the ECM is a central regulator (Fig. 2).

\section{The extracellular matrix and its contribution to gastric cancer progression}

Over the years, the ECM has received particular attention as a key regulator for tumor progression from the perspective of how its plasticity can alter the growth and metastatic potential of tumors and their response to biochemical cues originating from associated stromal cells [69]. In light of it maintaining essential aspects of tissue architecture and the organization of epithelial and auxiliary cells, the most important aspects of the ECM include its ability to modulate cellular survival, growth, and differentiation [70], morphogenesis, cellular adhesion, polarity and migration [71]. In the context of gastric epithelial cells and GC, how the ECM modulates the tumor microenvironment (TME) has revealed a number of very important findings, related to how premalignant lesions progress toward gastric adenocarcinoma in the presence of inflammation [72]. This process can be largely regulated through alterations in the rate of the synthesis and breakdown of structural and cellular components of the ECM [70].

Of particular relevance here are the stromal cells, some of which originate from bone marrow-derived stem cells (BMDSC) that can be recruited to chronically inflamed tissues [73] in response to IL-1 $\beta$, IL-6, TNF- $\alpha$ and the chemokine CXCL12 [74, 75]. At the tumor site, BMDSCs also have the capacity to differentiate into angiogenesis-promoting endothelial cells [76, 77], or TAFs [78] as a source of extracellular protease expression, TGF- $\beta$, VEGF, CXCL12, -14, -16, CCL2-5, IL-4 or IL-6 [79, 80], the collective interplay of which contributes to tumor progression. For example, TAF-derived IL-6 expression can direct the differentiation of monocytes to macrophages [81], while TAFs can also contribute to polarization of M1 (pro-inflammatory) macrophages to the M2 (anti-inflammatory) phenotype [82] and modulate immunosuppression through TGF- $\beta$ expression [83]. Here, macrophages can constitute over $50 \%$ of the tumor mass [84, 85], from which the M2 sub-type can support tumor survival and proliferation [86]. Similarly, tumor-infiltrating neutrophils (TINs) can help develop an immune-suppressive TME, through cytokine or chemokine release [87-90], while also having the capacity to differentiate into an N2 phenotype [91]. In the context of GC progression [92], TINs are believed to promote this by enhancing EMT of the gastric epithelium, through the activation of the ERK and JAK/STAT signaling pathways [93] or in response to IL-17 (Fig. 2) [94-96].

\section{Cathepsin proteases as key regulators of the extracellular matrix and tumor microenvironment}

A rapidly emerging group of proteases that can modulate the TME through the proteolysis of ECM components [97], membrane-associated cytokines [98], receptor proteins [99, 100] or cell-cell junction proteins, are the cathepsin proteases [101]. While originally characterized as important enzymes for lysosomal function, the cathepsins have recently come in to focus as being important 
in regulating a number of key aspects of disease pathology. Briefly, over 15 cathepsin proteases have been identified and can be sub-grouped into aspartic-, serine- and cysteine proteases, which are post-translationally processed as they traverse the secretory pathway and come to reside in the lysosomes [27]. However, under certain conditions (as in a number of cancer types), cathepsin protease expression is enhanced and significant levels of specific cathepsins are secreted to the extracellular milieu [102-105], either as mature proteases or inactive zymogens that can become activated during a decrease in the extracellular pH, Fig. 3 [106, 107].

Their extracellular localization is more common in a number of pathological conditions such as cancer, and can be derived from a number of sources, such as tumor cells or the auxiliary cells from the stroma [103, 104]. Mechanistically, secretion of cathepsins is thought to occur by vesicular exocytosis through lysosomes fusing with the plasma membrane, which can be triggered through increased intracellular $\mathrm{Ca}^{2+}$ ions [126, 127], JAK/STAT signaling [128, 129], or transcription factor EB activation [130]. Acidification of the ECM is another biochemical cue that enhances cathepsin secretion and is predominant within the microenvironment of tumors [131], atherosclerosis [132] and osteoarthritis [130]. Alternatively, increased levels of intracellular ROS or tumor suppressor protein p53 can also enhance leakage of some cathepsins through lysosomal membrane permeabilization (LMP), giving rise to their cytoplasmic localization [27, 133, 134]. Cathepsin proteases secreted into the ECM upon their overexpression, which have been diagnostically
Table 1 Cathepsin proteases reported to be overexpressed by specific cancers

\begin{tabular}{llll}
\hline Cathepsin & Amino acids (kDa) & Cancer type & References \\
\hline A & $480(54)$ & MM & {$[108,109]$} \\
B & $339(38)$ & MM, L, B, C, GB, H & {$[110,111]$} \\
D & $412(45)$ & B, L, O & {$[112,113]$} \\
H & $335(41)$ & GB & {$[114,115]$} \\
K & $329(39)$ & SCC, BCC, G & {$[116,117]$} \\
L & $333(38)$ & PC & {$[118-120]$} \\
S & $331(37)$ & C, GC & {$[121,122]$} \\
Z/X & $303(34)$ & PC, H & {$[123-125]$} \\
\hline
\end{tabular}

The amino acids and sizes of the cathepsin proteases overexpressed in malignant melanoma (MM), lung (L), breast (B), colon (C), glioblastoma (GB), hepatocarcinoma $(\mathrm{H})$, ovarian $(\mathrm{O})$, squamous cell carcinoma (SCC), basal cell carcinoma (BCC), glioma (G), prostate cancer (PC) and gastric cancer (GC) are highlighted

associated with the progression of certain cancer types or patient prognosis, are highlighted in Table $1[29,30]$.

Of central regulatory importance is the auto-catalytic activation of cysteine cathepsins (B, C, F, H, K, L, O, S, V, $\mathrm{Z} / \mathrm{X}, \mathrm{W})$ under mildly reducing and acidic conditions [135, 136], and which at neutral $\mathrm{pH}$ can be activated by negatively charged glycosaminoglycans (GAG) such as keratin and chondroitin sulfates [137], as seen for cathepsin $\mathrm{K}$ regulation [138]. For some of these cysteine cathepsins, their extracellular localization can give rise to a loss of activity, due to the neutral pH of the microenvironment [135]. However, such conditions can offer some favorable outcomes for other cysteine cathepsins through their stabilization, particularly if these proteases are secreted in their inactive zymogenic
Fig. 3 Cathepsin gene expression and protein trafficking in cancer and stromal cells. All 15 cathepsin proteases are synthesized as catalytically inactive pro-cathepsins, which are glycosylated as they pass through the secretory pathway. Maturation of pro-cathepsin proteases occurs upon their trafficking through the endosome or lysosome, resulting in their prodomain cleavage and removal. Under conditions of enhanced gene expression or specific cell-stimulatory cues, some cathepsin proteases are secreted and modulate the extracellular matrix (ECM)

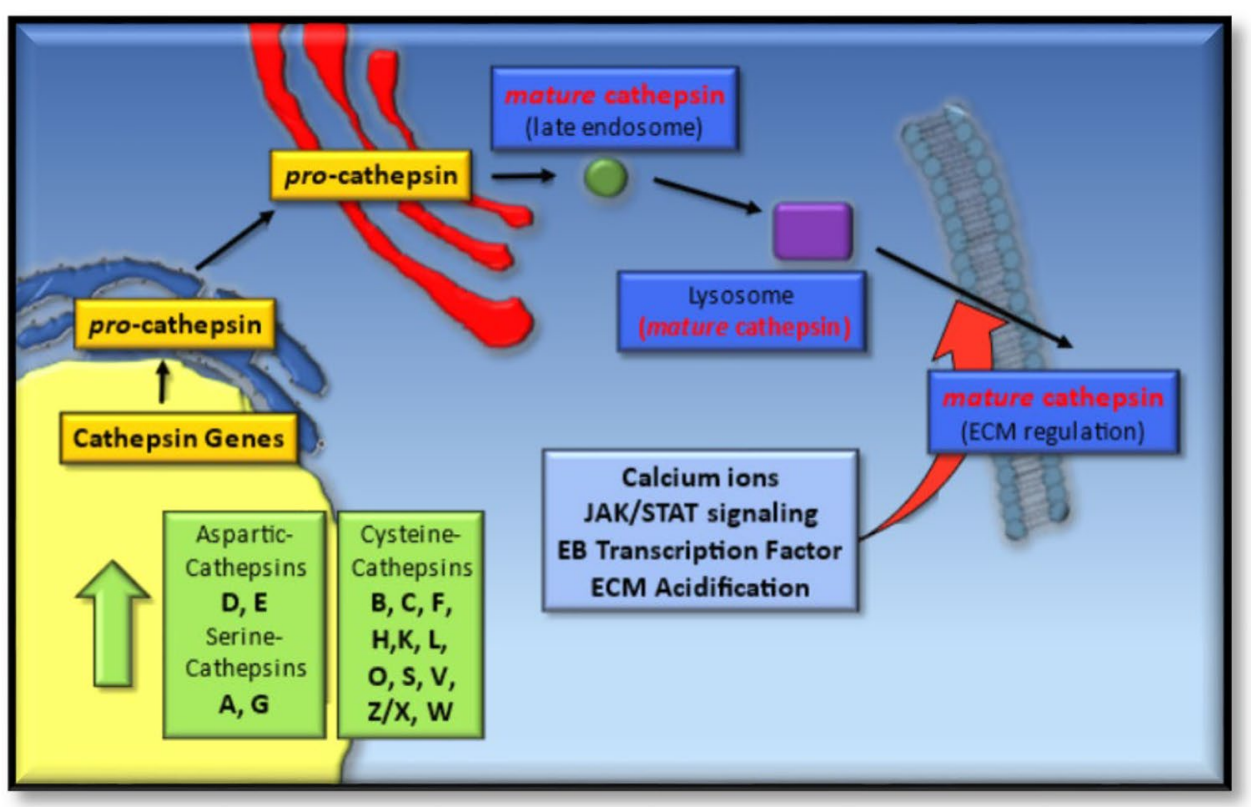


forms, and which can become auto-activated when a favorable drop in extracellular $\mathrm{pH}$ occurs through extracellular acidification. Such a pH-dependent auto-activation mechanism has been reported for pro-cathepsins $\mathrm{B}, \mathrm{K}, \mathrm{L}$ and $\mathrm{S}$ and their ability to cleave thyroglobin, in vitro [106]. Secreted mature cathepsins have the capacity to degrade ECM components [102], some of which can also modulate ECM signaling through their digestion products acting in an autocrine (or paracrine) manner (Table 2) and enhancing cathepsin expression or secretion [139].

Collectively, such regulatory aspects of cathepsin proteases have a high level of significance in them being able contribute to a number of important aspects of cancer pathology, such as the modulation of the ECM and infiltration of inflammatory cells and tumor development, growth and dispersal under extreme physiological conditions. As the mechanistic insights of how cathepsins are regulated transcriptionally and at the protein level may be cell type and context dependent, greater focus is indeed needed in delineating the effects of these factors exclusively in gastric cancer cell systems. Nevertheless, based on their significant input toward general cancer progression, they have long been viewed as good candidates for therapeutic targeting in addition to potential diagnostic or prognosis markers [29].

\section{Tumor and immune cell regulation by extracellular cathepsin proteases}

In addition to cathepsins secretion being enhanced from tumor cells, such proteases are also secreted from immune cells during inflammation (particularly from macrophages), thus directly regulating ECM dynamics and immune cell influx $[98,99]$. In addition to cleaving components of the ECM such as collagen and elastin [138, 151-154], cathepsins can also 'shed' inflammatory cytokines, chemokines
[155-159] or signaling receptor proteins [99, 152, 160], all of which have established or emerging importance in the co-modulation of inflammation and tumor progression. Of significance here are cathepsins $\mathrm{K}, \mathrm{A}, \mathrm{G}$ and $\mathrm{E}$, which have been demonstrated to be constitutively expressed within the epithelium of gastrointestinal cells of the stomach [27], with cathepsin D expression being recognized as a potentially reliably independent prognostic marker for GC [161]. Moreover, cathepsin S overexpression has been associated with GC invasiveness [162], and as a possible diagnostic and prognostic marker [163] for inflammation-induced spasmolytic polypeptide/trefoil factor 2-expressing metaplasia (SPEM) [164]. While some cathepsins have a limited range of tissue expression basally, it must be noted that some cathepsins, which are otherwise expressed at low levels, can be inducibly expressed and secreted under specific physiologically relevant conditions. This has been reported for enhanced cathepsin S expression under IL- $1 \alpha$ and TNF- $\alpha$ stimulatory conditions in human chondrocytes [128], and for cathepsin K expression under RANKL-stimulatory conditions in human osteoclast cells [165]. Moreover, some cathepsins have also taken on some importance based on potential changes in their expression profiles throughout the various stages leading to GC, the significance of which is coming into focus, as a broader picture develops from changes in their molecular expression to biological effects and disease progression (Table 3).

Additionally, infiltrating macrophages (cathepsins F, K, O), cytotoxic T lymphocytes (cathepsins C, W), APC (cathepsin S), monocytes (cathepsin G) and neutrophils (cathep$\sin \mathrm{G}$ ) also express specific cathepsin proteases. Here, cathepsin B is of importance based upon mouse myeloid-derived suppressor cells (MDSCs) failing to accumulate in the absence of cathepsin B expression, possibly due to the lack of TNF- $\alpha$-derived signaling cues $[175,176]$, whereas cathepsin $\mathrm{K}$ can contribute to macrophage infiltration and upon
Table 2 Cathepsin protease expression, their extracellular target proteins and the biological effects of their expression during cancer progression

\begin{tabular}{llll}
\hline Cathepsin & ECM substrate & Biological effects & References \\
\hline B, L, S & E-cadherin & Tumor invasiveness & {$[140]$} \\
B & CD18 & Angiogenesis & {$[100]$} \\
S & Nidogen-1 & NSLC invasiveness/angiogenesis & {$[141]$} \\
S & Canstaten/arresten & Angiogenesis & {$[142]$} \\
B, L & Lam./Fibron./COL IV & Tumor invasiveness & {$[143]$} \\
B & Tenascin-C & Oncogenesis & {$[144]$} \\
B, L, S & COL XVIII & Angiogenesis & {$[145,146]$} \\
K & Periostin & Breast cancer metastases & {$[147]$} \\
K & SPARC & Bone metastases & {$[148]$} \\
K,S,V & Elastin & Cardiovascular disease & {$[149]$} \\
B,L & Perlecan & Neuroprotection & {$[150]$} \\
\hline
\end{tabular}

Lam. laminin, Fibron. fibronectin, COL collagen, SPARC secreted protein acidic and rich in cysteine protein, NSLC non-small lung cancer 
Table 3 The stage-specific effects of intracellular cathepsin protease expression during gastric cancer development

\begin{tabular}{llll}
\hline Stage & Cathepsins (tissues) & Effects & References \\
\hline Chronic gastritis & $-\mathrm{X}(+)(\mathrm{GM}, \mathrm{MAC}, \mathrm{AM})$, & Invasiveness & {$[115]$} \\
& $-\mathrm{Z}(-)(\mathrm{GM})$ & EP, MI & {$[166]$} \\
& $-\mathrm{B},-\mathrm{L},-\mathrm{K}(\mathrm{nc})(\mathrm{E}, \mathrm{GM})$ & Late-stage GC & {$[167]$} \\
& $-\mathrm{X}(+)(\mathrm{E})$ & Shedding & {$[167]$} \\
& $-\mathrm{W}(+)(\mathrm{NK}, \mathrm{CTLs})$ & Cytotoxicity & {$[167]$} \\
Atrophic gastritis & $-\mathrm{W}(+)(\mathrm{NK}, \mathrm{CTLs})$ & Cytotoxicity & {$[168]$} \\
& $-\mathrm{Z}(-)(\mathrm{GM})$ & EP, MI & {$[166]$} \\
& $-\mathrm{B}(+)(\mathrm{E}, \mathrm{GM})$ & GCD & {$[169]$} \\
Intestinal metaplasia & $-\mathrm{L}(+)(\mathrm{E}, \mathrm{GM})$ & GCD & {$[169]$} \\
& $-\mathrm{Z}(-)(\mathrm{GM})$ & EP, MI & {$[166]$} \\
& $-\mathrm{B}(+)(\mathrm{E}, \mathrm{GM})$ & GCD & {$[169]$} \\
& $-\mathrm{L}(+)(\mathrm{E}, \mathrm{GM})$ & GCD & {$[169]$} \\
& $-\mathrm{E}(-)(\mathrm{GM})$ & Dedifferentiation & {$[170]$} \\
& $-\mathrm{E}(+)(\mathrm{GM}, \mathrm{IMG})$ & - & {$[171]$} \\
Dysplasia & $-\mathrm{B}(+)(\mathrm{E}, \mathrm{GM})$ & GCD & {$[169]$} \\
& $-\mathrm{L}(+)(\mathrm{E}, \mathrm{GM})$ & GCD & {$[169]$} \\
& $-\mathrm{E}(-)(\mathrm{GM})$ & Dedifferentiation & {$[170]$} \\
Gastric cancer & $-\mathrm{X}(+)(\mathrm{GCAR})$ & Invasiveness & {$[115]$} \\
& $-\mathrm{B}(+)(\mathrm{E})$ & Invasiveness & Proliferation \\
& $-\mathrm{B}(+) /-\mathrm{L}(+)(\mathrm{GM})$ & & {$[172]$} \\
& & & {$[173,174]$} \\
\hline
\end{tabular}

Cell-specific cathepsin proteases expression profiles are highlighted in relation to the biological effects they have been linked to during GC development (GCD). GM gastric mucosa, $M A C$ macrophage, $A M$ antral mucosa, $E$ epithelial, $E P$ epithelial proliferation, $M I$ macrophage infiltration, $N K$ natural killer cells, $C T L$ cytotoxic T cells, $I M G$ intestinal metaplastic glands, GCAR gastric carcinoma cells, $C D$ cellular differentiation. Expression patterns are highlighted as induced (+), deficiency $(-)$ and no change (nc) overexpression of cathepsin B can give elevated CCL2 and COX2 expression [177], thus favoring MDSC expansion. Additionally, CCL2 has been reported as potently attracting BMDSCs, such as TAMs, to the tumor site [178] and have the capacity to upregulate cathepsin expression based on their responsiveness to IL-4, -6 and -10 stimulation [98]. The significance of TAMs and the effects of their cathepsin expression capabilities in disease progression have been highlighted by a number of excellent mouse studies [179]. For example, TAM-derived cathepsins B, H and S had a predominantly negative effect in RIP1-Tag2 pancreatic neuroendocrine cancer progression [98], whereas tumor-derived cathepsin $\mathrm{L}$ contributed to cancer progression.

The specific substrates that these cathepsins manifest their activity toward is also an emerging area of interest, which has yielded a number of insightful findings into GC progression. For example, differentiation of BMDSCs to macrophages, neutrophils and dendritic cells is driven by tumor- and ECM-derived growth factors and cytokines [180]. In support, cathepsin expression is required for macrophage survival, which is otherwise deficient during impaired autophagy responsiveness, and leads to their apoptosis through mitochondrial damage-mediated ROS generation [181]. Moreover, cathepsin S expression also contributes to the polarization of macrophages from types M1 to
M2 [182], in addition to autophagosome-lysosome fusion [182], as does cathepsin K expression through its activation of TLR-4 [183], thus collectively contributing to the development of a TME that is supportive of tumor growth $[184,185]$. Of note, cathepsin-mediated TLR cleavage and activation is also essential for dendritic cell function [186] as another significant cellular contributor to TME, based on TLR-4 expression synergizing with cancer cell progression by it positively regulating EMT [187].

Similarly, tumor-infiltrating neutrophils (TINs) have also been reported to shift their phenotype from N1 to the tumorpromoting $\mathrm{N} 2$ sub-type in a cathepsin expression-dependent manner. Here, cathepsin $\mathrm{C}$ plays a central role as seen in Papillon-Lefèvre syndrome in humans, where a lack of cathepsin C expression impairs neutrophil function, giving rise to erythematous palmoplantar hyperkeratosis and early-onset periodontitis [188]. Moreover, neutrophil survival has been reported to be lysosomal cathepsins $\mathrm{B}$ and $\mathrm{D}$ expression dependent, both of which can contribute to the initiation of apoptotic cascades through caspase- 8 activation and BID cleavage $[189,190]$. Alternatively, cathepsin D can mediate VacA proteolysis in autophagosomes and is a protease that is also required for the correct execution of autophagy [48].

As detailed, extracellular cathepsins affect immune cell physiology, through cytokine, chemokine and receptor 
shedding or cleavage [103]. Functionally, they can activate pro-inflammatory ELR chemokines, deactivate nonELR chemokines or regulate chemotaxis and angiogenesis, as seen with cathepsins S, L and K [103]. Cathepsin $\mathrm{S}$ expression can also permit the infiltration of monocytes and macrophages through the basement membrane [191], whereas cathepsin K expression has anti-microbial effects in intestinal goblet cells, as seen from cathepsin $\mathrm{K}^{-1-}$ mice, which developed severe colitis and altered gut microbial communities [192].

In summary, tumor or immune cell-derived cathepsin proteases carry significance in modulating the TME exclusively or in concert with other ECM-derived protein factors, which can favor unbridled inflammation, tumor growth and development in a variety of ways. Such emerging regulatory relationships highlight an elevated level of complexity, based on whether the cathepsins are derived from the tumor or immune cells and whether they exhibit effects at the intracellular and extracellular levels, or a combination of both (Figs. 2, 4). In large, such findings are modeled on a diverse number of cancer-type paradigms. To clarify, research efforts are being helped through addressing the dispensability of individual cathepsin proteases, exclusively or in combinations, during cancer initiation and progression through the use of knockout-mouse studies, the findings from which could be extended to offer greater correlative insights when exclusively profiled with the various stages of the Correa model for GC development.

\section{Adaptive immunity regulation by intracellular cathepsin proteases}

Of additional significance are the effects of cathepsin proteases in the regulation of adaptive immunity and immune surveillance, through regulating the responsiveness of natural killer (NK) cells and cytotoxic T cells (CTLs) during disease progression. Herein, while the mechanistic recognition of newly formed antigens can be recognized by $\mathrm{CD} 8^{+}$ and $\mathrm{CD}^{+} \mathrm{CTLs}$, through $\mathrm{MHCI}$ and TCR engagement, one key regulatory step for T-cell activation is the co-stimulatory secondary signal derived from CD28-CD80/CD86 engagement between $\mathrm{T}$ cell and antigen-presenting cell (APC) [193]. In this context, co-inhibitory signals may also arise as in the case of tumor cells expressing receptors PD-1, LAG-3, and Tim-3, which when bound to their cognate ligands on $\mathrm{T}$ cells, induce T-cell inactivation. In the instance of PD-1, it can bind one of its two ligands, namely PD-L1 [194-196]. Of equal importance are the MHCII molecules, which also display tumor or pathogen-derived antigens, as on APCs such as dendritic cells, or macrophages, and which subsequently bind the LAG-3 ligand on activated T cells and NK cells, and inhibit their activation [197, 198]. One alternative mechanism by which tumor cells may overcome cytotoxic CTL-mediated tumor cell death is through downregulation of tumor antigen expression, leading to a reduction in $\mathrm{CD}^{+}{ }^{+} \mathrm{T}$-helper cell activation and active CTLs [28]. In this context, the fate of the invariant chain 'Li' protein (CD74) is of fundamental importance. Specifically, it is required for MHCII-antigenic peptide charging [199], following its cleavage by the proteolytic activity of cathepsin L. However,
Fig. 4 The diverse actions and cellular origins of the cathepsin proteases during gastric cancer progression. Schematic highlighting the various cathepsin proteases which have been characterized as being important in gastric cancer progression, when either derived from gastric epithelial cells or tumor-associated macrophages (TAMs), tumor-infiltrating neutrophils (TINs), Cytotoxic $\mathrm{T}$ cells $(\mathrm{CTL})$ and natural killer cells (NK) from the innate or adaptive immune systems

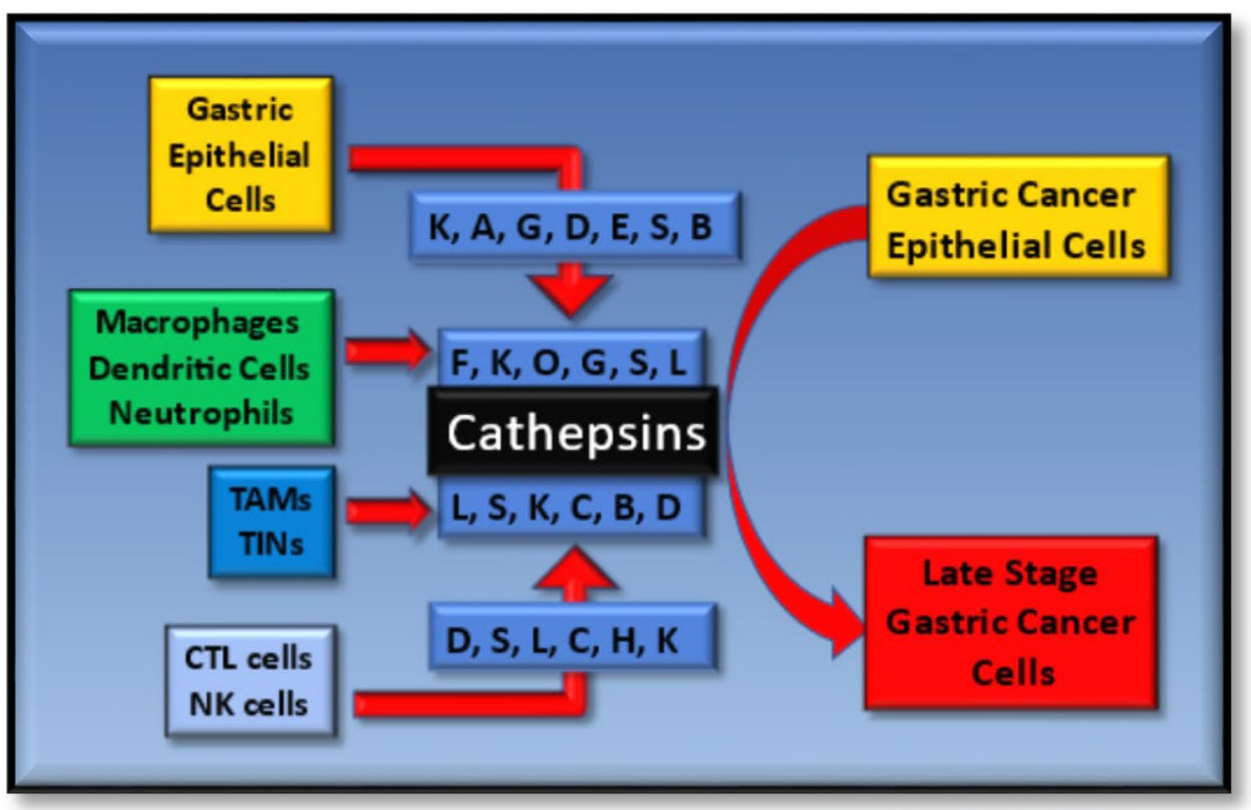


complete deactivation of ' $\mathrm{Li}$ ' protein can also occur through its degradation by other cathepsin proteases [200], such as cathepsins B [201], G [202] or S [200], thus highlighting a central immunosuppressive property of such proteases on naïve T-cell activation. Key negative regulation of MHCII protein expression can also occur under IL-6 and IL-10 stimulatory conditions and offer dendritic cell tolerance, where IL-6 signals can exclusively reduce the protein levels of the invariant chain, through enhanced cathepsin S activity [203]. Moreover, CCL2 expression has also been associated with cathepsin S-mediated cleavage of the invariant chain, after which the liberated intracellular domain of CD74 can translocate to the nucleus and activate transcription factor NF- $\mathrm{\kappa B}$ and CCL2 transcription [178]. Such a mechanism could also be viewed as a feedback loop that helps drive the influx of BMDSC and TAMs to the site of the tumor.

The role of cathepsin proteases and their expression are also coming into focus as being key players in additional aspects of the inflammatory and immune response. Expression of cathepsins D or $\mathrm{S}$ and cystatin $\mathrm{C}$ were reported to modulate the differentiation of immunogenic dendritic cells to an immunotolerant phenotype in a time-dependent manner [204]. Here, TLRs have been reported to enhance immunotolerance through their regulated expression of IL- $1 \beta$ and IL-6 in tumor and stromal cells [205]. As demonstrated, TLRs 3, 7, and 9 can be processed by cathepsin proteases during the second stage of a two-step cleavage reaction in macrophages, dendritic cells and fibroblasts, to permit efficient TLR-nucleic acid sensing [186]. In the instance of secreted cathepsin $\mathrm{K}$, it could also polarize M1 macrophages to M2 through TLR-4 processing and activation [183], which is viewed as an important aspect of M2 macrophage-tumor cross talk for EMT progression of cancer cells [187].

In combination with the above, NK cells can target poorly differentiated tumors and cancer stem cells expressing low levels of MHCI [206], through activating tumor death receptor signaling pathways or upon perforin and granzymes release. The latter can be stored as inactive precursors, which can also be cleaved and activated by cathepsin proteases L, C and H [207, 208]. Such effects can also be negatively regulated upon intracellular cystatin $\mathrm{F}$ expression [209], or upon the exposure of NK cells to exogenous cystatin F protein [210], which gives rise to reduced NK cell-mediated cytotoxicity [209, 211].

In summary, intracellular cathepsins D, S, L, C, H and $\mathrm{K}$ clearly have significant and diverse positive and negative regulatory roles within the adaptive immune response and their expression contributes to immunosurveillance, macrophage polarization, cell-mediated cytotoxicity and dendritic cell maturation. While the complexity of such mechanisms do highlight overlapping roles and effects, such key regulatory roles do have great significance in being considered further, particularly if exploited as potential targets for
GC therapy in a Correa stage-specific model for GC development and progression (Figs. 1, 4).

\section{Current treatments for $\boldsymbol{H}$. pylori-mediated gastric cancer}

Observational studies have been conclusive in linking $H$. pylori infection with increased GC risk [14], as seen with the eradication of $H$. pylori infection decreasing such a risk by approximately $40 \%$ in asymptomatic patients and recurrence by $54 \%$ in individuals who had undergone endoscopic resection for GC [212, 213]. Currently, the recognized critical point, beyond which the eradication of $H$. pylori does not prevent the progression of GC, is between the Correa model stages of metaplasia and dysplasia. While in some studies where GC had a high prevalence (such as in SE Asia), a risk reduction was observed through $H$. pylori eradication programs [213], uncertainty remains as to whether such findings can be extrapolated to countries where there is a low prevalence. Available therapeutic regimes for GC are very diverse and can take a number of forms based on the stage of development. For example, the use of proton pump inhibitors (PPIs) are universally administered for the treatment of H. pylori infection during chronic gastritis [214], and their efficacy can be improved when offered in a combined therapy along with antibiotics, such as clarithromycin, amoxicillin and metronidazole [215].

In addition to the Correa model for GC, histological Borrmann classifications based upon macroscopic appearance [216] can also allow patients to be sub-grouped, followed by staging, surgical and endoscopic resection or chemotherapy. Of importance, chemotherapy before curative resection can also offer enhanced 5-year survival rates and cure rates of up to $40 \%$, and is the recommended standard treatment for patients with locally advanced GC [217-219]. The emerging use of antibody therapeutics has offered encouragement, based on them being able to activate host immunity in cancer cell recognition and clearance [220], as have the alternative uses of cytokine-induced killer (CIK) cell therapy [221]. Here, immune checkpoint antibody inhibitors that can block immunosuppressive signals are offering a promising approach. For example, the use of pembrolizumub has showed an encouraging 6-month progression-free survival of $24 \%$ and an overall survival (OS) of $33 \%$, in treating late-stage GC patients [222]. As a more recent example, trastuzumab deruxtecan is also showing encouraging outcomes for the treatment of HER2-positive pre-treated GC patients following phase I/II clinical trials [223, 224]. As a next-generation antibody therapeutic, it is composed of an anti-Her2 antibody fused to the topoisomerase I inhibitor DXd, through a cleavable linker and showed enhanced objective response rates and overall survival of patients who 
Table 4 Selective antibody therapeutics currently being trialed in combination or as pre-treatments with conventional chemotherapeutics

\begin{tabular}{|c|c|c|c|c|c|}
\hline Therapeutic (disease) & Combined therapeutic & GC target (cell type) & Target effects in GC & Cathepsin expression & References \\
\hline Ramucirumab (GC) & Paclitaxel & $\begin{array}{l}\text { VEGFR-2 } \\
\text { (tumor) }\end{array}$ & $\begin{array}{l}\text { Angiogenesis, } \\
\text { metastasis }\end{array}$ & Uk & {$[233]$} \\
\hline Sorafenib (GC) & $\begin{array}{l}\text { Cisplatin } \\
\text { Docetaxel }\end{array}$ & $\begin{array}{l}\text { VEGFR1-3 } \\
\text { (tumor) }\end{array}$ & $\begin{array}{l}\text { Angiogenesis, } \\
\text { metastasis }\end{array}$ & Cathepsin B (+) & $\begin{array}{l}{[234]} \\
{[235]}\end{array}$ \\
\hline Bevacizumab (RP/GC) & $\begin{array}{l}\text { Irinotecan } \\
\text { Cisplatin }\end{array}$ & $\begin{array}{l}\text { VEGF-A-L } \\
\text { (tumor) }\end{array}$ & $\begin{array}{l}\text { Angiogenesis, } \\
\text { metastasis }\end{array}$ & $\begin{array}{l}\text { Uk } \\
\text { Cathepsin D (+) }\end{array}$ & $\begin{array}{l}{[236]} \\
{[237]}\end{array}$ \\
\hline Centuximab (GC) & Cisplatin & EGF-R (tumor) & $\begin{array}{l}\text { Proliferation, } \\
\text { migration, Ang }\end{array}$ & Uk & {$[238]$} \\
\hline Panitumumab (OS/GC) & $\begin{array}{l}\text { Docetaxel } \\
\text { Cisplatin }\end{array}$ & $\begin{array}{l}\text { EGF-R } \\
\text { (tumor) }\end{array}$ & $\begin{array}{l}\text { Proliferation, } \\
\text { migration, Ang }\end{array}$ & $\begin{array}{l}\text { Uk } \\
\text { Uk }\end{array}$ & $\begin{array}{l}{[239]} \\
{[240]}\end{array}$ \\
\hline Nimotuzumab (GC) & $\begin{array}{l}\text { Cisplatin } \\
\text { Docetaxel/Cisplatin }\end{array}$ & $\begin{array}{l}\text { EGF-R } \\
\text { (tumor) }\end{array}$ & $\begin{array}{l}\text { Proliferation, } \\
\text { migration, Ang }\end{array}$ & $\begin{array}{l}\text { Uk } \\
\text { Uk }\end{array}$ & $\begin{array}{l}{[241]} \\
{[242]}\end{array}$ \\
\hline Avelumab (CRC) & - & $\begin{array}{l}\text { PD-1L } \\
\text { (tumor) }\end{array}$ & $\begin{array}{l}\text { Imm. Surv } \\
\text { TME,TCF }\end{array}$ & Uk & {$[243,244]$} \\
\hline $\begin{array}{l}\text { Pembrolizumab (CRC) } \\
\text { Nivolumab (GC) }\end{array}$ & $\begin{array}{l}- \\
\text { Pre-treatment }\end{array}$ & $\begin{array}{l}\text { PD-1 } \\
\text { (T cell) }\end{array}$ & $\begin{array}{l}\text { Imm. Surv } \\
\text { TME, TCF }\end{array}$ & $\begin{array}{l}\text { Uk } \\
\text { Uk }\end{array}$ & $\begin{array}{l}{[222]} \\
{[245]}\end{array}$ \\
\hline Trastuzumab deruxtecan (GC) & Anti-PD-1 & $\begin{array}{l}\text { EGF-R2 } \\
\text { (tumor) }\end{array}$ & $\begin{array}{l}\text { Imm. Surv } \\
\text { migration }\end{array}$ & $\mathrm{Uk}$ & [246] \\
\hline
\end{tabular}

Target proteins and their effects on gastric cancer progression or cathepsin protease expression are highlighted. $G C$ gastric cancer, $C R C$ colorectal cancer, $R P$ retinal pigment cells, $O S$ esophagogastric cancer, $V E G F$ vascular endothelial growth factor, Imm. Surv. immunosurveillance, $T M E$ tumor microenvironment, Ang. angiogenesis, TCF T-cell function; induced (+); decreased (-); unchanged (u); unknown (Uk)

had previously received at least two lines of chemotherapy [225]. Additionally, trastuzumab combined with fluoropyrimidine and platinum chemotherapy has also been seen to prolong the OS of patients with HER-2-positive inoperable GCs [226]. Other excellent chemotherapeutics that also show great potential for such uses include platinum-fluoropyrimidene [227-229], cisplatin, oxaliplatin, irinotecan and fluoropyrimidines [230]. Moreover, cell cycle inhibitors such as flavopiridol have also gained some attention recently, based on their promising efficacy as small molecule inhibitors that can target the cyclin-dependent kinases [231], and are currently being administered as combined therapeutics with docetaxel in GC therapy [232]. Finally, how such therapeutic regimens modulate cathepsin protease activity or expression is also an area of significance, based on the input these proteases have on regulation of inflammation or cancer progression, and therefore warrant further evaluation in such studies (Table 4).

To summarize, the treatments offered for GC development beyond the $H$. pylori infection stage generally offer limited curative success or OS of patients up to 5 years or beyond, and while combined strategies show some encouraging outcomes, alternative strategies do need to be given greater consideration, for which the input of the intracellular or extracellular cathepsin proteases cannot be ignored.

\section{Conclusions}

In conclusion, the effects that microbes can have in relation to disease onset are very real and in some instances are also being unveiled as an integral part of disease progression. In the context of $H$. pylori, its role in $\mathrm{GC}$ onset and progression is relatively asymptomatic, but over time can give rise to tangible effects with life-threatening consequences. While the initial inert effects of $H$. pylori infection can be addressed in the clinic with relative ease, its long-term effects culminating through chronic inflammation to GC progression offer little in the way of effective therapy outside of surgical resection. Throughout GC progression, a whole array of significant biological and physiological effects can take place, which offer the basic research communities a number of significant areas for exploration, with a view to mechanistically defining with greater clarity the regulation of the immune response and how it appears to be 'annexed' by developing tumors to aid their own progression. While not all types of cancers may share such an etiological component, the growing recognition of the immune response and its involvement in cancer development are nevertheless firmly established. At the cellular level, the input of neutrophils, dendritic cells, macrophages, mast cells and cells from the adaptive immune system share a very complex relationship and, through sheer 
resilience, the scientific community is unravelling the relationships such cellular components share with each other or with the tumor, and particularly in the context of GC progression. At the heart of this is the dynamic relationship shared by the immune system, the ECM and the TME in permitting a whole raft of effects to take place in permitting the growth of tumor cells, their metastasis and vascularization. Indeed, key proteins that help in modulating such a dynamic at the molecular level, which are being viewed to carry significance throughout disease progression, are the cathepsin proteases. While originally thought to be just lysosomal proteases, essential to the process of protein degradation, they are without question emerging as essential players during microbial-mediated disease progression, through their diverse activities extracellularly and within the cell.

Acknowledgements We would like to acknowledge Prof Paul A Townsend (University of Surrey) for proofreading this manuscript.

Author contributions Conception, research, writing and editing: SMS. Discussions, editing and proofreading: AAZ.

Funding This research was funded by the Russian Science Foundation (Grant\# 21-75-30020).

Availability of data and material All data pertaining to this manuscript is available for scrutiny upon request.

\section{Declarations}

Conflicts of interest There are no competing interests.

Ethics approval Not applicable.

Consent to participate Not applicable.

Consent for publication Surinder M Soond (SMS) and Andrey A Zamyatnin Jr (AAZ) both give their consent for publication.

Open Access This article is licensed under a Creative Commons Attribution 4.0 International License, which permits use, sharing, adaptation, distribution and reproduction in any medium or format, as long as you give appropriate credit to the original author(s) and the source, provide a link to the Creative Commons licence, and indicate if changes were made. The images or other third party material in this article are included in the article's Creative Commons licence, unless indicated otherwise in a credit line to the material. If material is not included in the article's Creative Commons licence and your intended use is not permitted by statutory regulation or exceeds the permitted use, you will need to obtain permission directly from the copyright holder. To view a copy of this licence, visit http://creativecommons.org/licenses/by/4.0/.

\section{References}

1. Ferlay J, Colombet M, Soerjomataram I, Mathers C, Parkin DM, Pineros M, et al. Estimating the global cancer incidence and mortality in 2018: GLOBOCAN sources and methods. Int J Cancer. 2019;144(8):1941-53.

2. Mommersteeg MC, Yu J, Peppelenbosch MP, Fuhler GM. Genetic host factors in Helicobacter pylori-induced carcinogenesis: emerging new paradigms. Biochim Biophys Acta Rev Cancer. 2018;1869(1):42-52.

3. Moss SF. The clinical evidence linking Helicobacter pylori to gastric cancer. Cell Mol Gastroenterol Hepatol. 2017;3(2):183-91.

4. Garrett WS. Cancer and the microbiota. Science. 2015;348(6230):80-6.

5. Balkwill F, Mantovani A. Inflammation and cancer: back to Virchow? Lancet. 2001;357(9255):539-45.

6. Munn LL. Cancer and inflammation. Wiley Interdiscip Rev Syst Biol Med. 2017. https://doi.org/10.1002/wsbm.1370.

7. Grivennikov SI. Inflammation and colorectal cancer: colitisassociated neoplasia. Semin Immunopathol. 2013;35(2):229-44.

8. Grivennikov SI, Greten FR, Karin M. Immunity, inflammation, and cancer. Cell. 2010;140(6):883-99.

9. Elkahwaji JE, Zhong W, Hopkins WJ, Bushman W. Chronic bacterial infection and inflammation incite reactive hyperplasia in a mouse model of chronic prostatitis. Prostate. 2007;67(1):14-21.

10. Herszenyi L, Miheller P, Tulassay Z. Carcinogenesis in inflammatory bowel disease. Dig Dis. 2007;25(3):267-9.

11. Ehling J, Tacke F. Role of chemokine pathways in hepatobiliary cancer. Cancer Lett. 2016;379(2):173-83.

12. Hooi JKY, Lai WY, Ng WK, Suen MMY, Underwood FE, Tanyingoh D, et al. Global prevalence of Helicobacter pylori infection: systematic review and meta-analysis. Gastroenterology. 2017;153(2):420-9.

13. Schistosomes, liver flukes and Helicobacter pylori. IARC Working Group on the Evaluation of Carcinogenic Risks to Humans. Lyon, 7-14 June 1994. IARC Monogr Eval Carcinog Risks Hum 1994, 61:1-241

14. Uemura N, Okamoto S, Yamamoto S, Matsumura N, Yamaguchi $\mathrm{S}$, Yamakido M, et al. Helicobacter pylori infection and the development of gastric cancer. N Engl J Med. 2001;345(11):784-9.

15. Peek RM Jr, Crabtree JE. Helicobacter infection and gastric neoplasia. J Pathol. 2006;208(2):233-48.

16. Warren JR, Marshall B. Unidentified curved bacilli on gastric epithelium in active chronic gastritis. Lancet. 1983;1(8336):1273-5.

17. Marshall BJ, Warren JR. Unidentified curved bacilli in the stomach of patients with gastritis and peptic ulceration. Lancet. 1984;1(8390):1311-5.

18. Pereira-Marques J, Ferreira RM, Pinto-Ribeiro I, Figueiredo C. Helicobacter pylori infection, the gastric microbiome and gastric cancer. Adv Exp Med Biol. 2019;1149:195-210.

19. Johnson KS, Ottemann KM. Colonization, localization, and inflammation: the roles of $H$. pylori chemotaxis in vivo. Curr Opin Microbiol. 2018;41:51-7.

20. Correa P. Human gastric carcinogenesis: a multistep and multifactorial process-first American Cancer Society Award Lecture on Cancer Epidemiology and Prevention. Cancer Res. 1992;52(24):6735-40.

21. Blaser MJ, Atherton JC. Helicobacter pylori persistence: biology and disease. J Clin Invest. 2004;113(3):321-33.

22. Mouw JK, Ou G, Weaver VM. Extracellular matrix assembly: a multiscale deconstruction. Nat Rev Mol Cell Biol. 2014;15(12):771-85.

23. Rozario T, DeSimone DW. The extracellular matrix in development and morphogenesis: a dynamic view. Dev Biol. 2010;341(1):126-40.

24. Kular JK, Basu S, Sharma RI. The extracellular matrix: structure, composition, age-related differences, tools for analysis and applications for tissue engineering. J Tissue Eng. 2014;5:2041731414557112. 
25. Sternlicht MD, Lochter A, Sympson CJ, Huey B, Rougier JP, Gray JW, et al. The stromal proteinase MMP3/stromelysin-1 promotes mammary carcinogenesis. Cell. 1999;98(2):137-46.

26. Mott JD, Werb Z. Regulation of matrix biology by matrix metalloproteinases. Curr Opin Cell Biol. 2004;16(5):558-64.

27. Soond SM, Kozhevnikova MV, Zamyatnin AA Jr. "Patchiness" and basic cancer research: unravelling the proteases. Cell Cycle. 2019;18(15):1687-701.

28. Jakos T, Pislar A, Pecar Fonovic U, Kos J. Lysosomal peptidases in innate immune cells: implications for cancer immunity. Cancer Immunol Immunother. 2020;69(2):275-83.

29. Soond SM, Kozhevnikova MV, Townsend PA, Zamyatnin AA Jr. Cysteine cathepsin protease inhibition: an update on its diagnostic, prognostic and therapeutic potential in cancer. Pharmaceuticals (Basel). 2019;12(2):87.

30. Alfarouk KO, Bashir AHH, Aljarbou AN, Ramadan AM, Muddathir AK, AlHoufie STS, et al. The possible role of Helicobacter pylori in gastric cancer and its management. Front Oncol. 2019;9:75.

31. Malfertheiner P. Helicobacter pylori treatment for gastric cancer prevention. N Engl J Med. 2018;378(12):1154-6.

32. Wong BC, Lam SK, Wong WM, Chen JS, Zheng TT, Feng RE, et al. Helicobacter pylori eradication to prevent gastric cancer in a high-risk region of China: a randomized controlled trial. JAMA. 2004;291(2):187-94.

33. Rugge M, Meggio A, Pravadelli C, Barbareschi M, Fassan M, Gentilini M, et al. Gastritis staging in the endoscopic followup for the secondary prevention of gastric cancer: a 5-year prospective study of 1755 patients. Gut. 2019;68(1):11-7.

34. Censini S, Lange C, Xiang Z, Crabtree JE, Ghiara P, Borodovsky M, et al. cag, a pathogenicity island of Helicobacter pylori, encodes type I-specific and disease-associated virulence factors. Proc Natl Acad Sci USA. 1996;93(25):14648-53.

35. Odenbreit S, Puls J, Sedlmaier B, Gerland E, Fischer W, Haas R. Translocation of Helicobacter pylori CagA into gastric epithelial cells by type IV secretion. Science. 2000;287(5457):1497-500.

36. Fischer W, Puls J, Buhrdorf R, Gebert B, Odenbreit S, Haas R. Systematic mutagenesis of the Helicobacter pylori cag pathogenicity island: essential genes for CagA translocation in host cells and induction of interleukin-8. Mol Microbiol. 2001;42(5):1337-48.

37. Ogura K, Maeda S, Nakao M, Watanabe T, Tada M, Kyutoku T, et al. Virulence factors of Helicobacter pylori responsible for gastric diseases in Mongolian gerbil. J Exp Med. 2000;192(11):1601-10.

38. Tegtmeyer N, Wessler S, Backert S. Role of the cag-pathogenicity island encoded type IV secretion system in Helicobacter pylori pathogenesis. FEBS J. 2011;278(8):1190-202.

39. Grubman A, Kaparakis M, Viala J, Allison C, Badea L, Karrar A, et al. The innate immune molecule, NOD1, regulates direct killing of Helicobacter pylori by antimicrobial peptides. Cell Microbiol. 2010;12(5):626-39.

40. Fiocca R, Necchi V, Sommi P, Ricci V, Telford J, Cover TL, et al. Release of Helicobacter pylori vacuolating cytotoxin by both a specific secretion pathway and budding of outer membrane vesicles. Uptake of released toxin and vesicles by gastric epithelium. J Pathol. 1999;188(2):220-6.

41. Xu X, Liu Z, Fang M, Yu H, Liang X, Li X, et al. Helicobacter pylori $\mathrm{CagA}$ induces ornithine decarboxylase upregulation via Src/MEK/ERK/c-Myc pathway: implication for progression of gastric diseases. Exp Biol Med (Maywood). 2012;237(4):435-41.

42. Mueller D, Tegtmeyer N, Brandt S, Yamaoka Y, De Poire E, Sgouras D, et al. c-Src and c-Abl kinases control hierarchic phosphorylation and function of the CagA effector protein in
Western and East Asian Helicobacter pylori strains. J Clin Invest. 2012;122(4):1553-66.

43. Higashi H, Tsutsumi R, Muto S, Sugiyama T, Azuma T, Asaka M, et al. SHP-2 tyrosine phosphatase as an intracellular target of Helicobacter pylori CagA protein. Science. 2002;295(5555):683-6.

44. Mimuro H, Suzuki T, Nagai S, Rieder G, Suzuki M, Nagai T, et al. Helicobacter pylori dampens gut epithelial self-renewal by inhibiting apoptosis, a bacterial strategy to enhance colonization of the stomach. Cell Host Microbe. 2007;2(4):250-63.

45. Akazawa $\mathrm{Y}$, Isomoto H, Matsushima K, Kanda T, Minami H, Yamaghchi N, et al. Endoplasmic reticulum stress contributes to Helicobacter pylori VacA-induced apoptosis. PLoS ONE. 2013;8(12):e82322.

46. Galmiche A, Rassow J, Doye A, Cagnol S, Chambard JC, Contamin $\mathrm{S}$, et al. The $\mathrm{N}$-terminal $34 \mathrm{kDa}$ fragment of Helicobacter pylori vacuolating cytotoxin targets mitochondria and induces cytochrome c release. EMBO J. 2000;19(23):6361-70.

47. Tsugawa H, Suzuki H, Saya H, Hatakeyama M, Hirayama T, Hirata K, et al. Reactive oxygen species-induced autophagic degradation of Helicobacter pylori CagA is specifically suppressed in cancer stem-like cells. Cell Host Microbe. 2012;12(6):764-77.

48. Raju D, Hussey S, Ang M, Terebiznik MR, Sibony M, GalindoMata E, et al. Vacuolating cytotoxin and variants in Atg16L1 that disrupt autophagy promote Helicobacter pylori infection in humans. Gastroenterology. 2012;142(5):1160-71.

49. Kalisperati P, Spanou E, Pateras IS, Korkolopoulou P, Varvarigou A, Karavokyros I, et al. Inflammation, DNA damage, Helicobacter pylori and gastric tumorigenesis. Front Genet. 2017;8:20.

50. Brandt S, Kwok T, Hartig R, Konig W, Backert S. NF-kappaB activation and potentiation of proinflammatory responses by the Helicobacter pylori CagA protein. Proc Natl Acad Sci USA. 2005;102(26):9300-5.

51. Watanabe T, Arakawa T, Fukuda T, Higuchi K, Kobayashi K. Role of neutrophils in a rat model of gastric ulcer recurrence caused by interleukin-1 beta. Am J Pathol. 1997;150(3):971-9.

52. Minaga K, Watanabe T, Kamata K, Asano N, Kudo M. Nucleotide-binding oligomerization domain 1 and Helicobacter pylori infection: a review. World J Gastroenterol. 2018;24(16):1725-33.

53. Amieva MR, Vogelmann R, Covacci A, Tompkins LS, Nelson WJ, Falkow S. Disruption of the epithelial apicaljunctional complex by Helicobacter pylori CagA. Science. 2003;300(5624):1430-4.

54. Yamaoka Y, Kita M, Kodama T, Sawai N, Kashima K, Imanishi J. Induction of various cytokines and development of severe mucosal inflammation by cagA gene positive Helicobacter pylori strains. Gut. 1997;41(4):442-51.

55. El-Omar EM, Oien K, El-Nujumi A, Gillen D, Wirz A, Dahill $\mathrm{S}$, et al. Helicobacter pylori infection and chronic gastric acid hyposecretion. Gastroenterology. 1997;113(1):15-24.

56. Tu S, Bhagat G, Cui G, Takaishi S, Kurt-Jones EA, Rickman B, et al. Overexpression of interleukin-1beta induces gastric inflammation and cancer and mobilizes myeloid-derived suppressor cells in mice. Cancer Cell. 2008;14(5):408-19.

57. Motta V, Soares F, Sun T, Philpott DJ. NOD-like receptors: versatile cytosolic sentinels. Physiol Rev. 2015;95(1):149-78.

58. Tran LS, Chonwerawong M, Ferrero RL. Regulation and functions of inflammasome-mediated cytokines in Helicobacter pylori infection. Microbes Infect. 2017;19(9-10):449-58.

59. Piras V, Selvarajoo K. Beyond MyD88 and TRIF pathways in toll-like receptor signaling. Front Immunol. 2014;5:70.

60. Velloso FJ, Trombetta-Lima M, Anschau V, Sogayar MC, Correa RG. NOD-like receptors: major players (and targets) in the interface between innate immunity and cancer. 2019. Biosci Rep. https://doi.org/10.1042/BSR20181709. 
61. Jo EK, Kim JK, Shin DM, Sasakawa C. Molecular mechanisms regulating NLRP3 inflammasome activation. Cell Mol Immunol. 2016;13(2):148-59.

62. Murata-Kamiya N, Kurashima Y, Teishikata Y, Yamahashi Y, Saito Y, Higashi H, et al. Helicobacter pylori CagA interacts with E-cadherin and deregulates the beta-catenin signal that promotes intestinal transdifferentiation in gastric epithelial cells. Oncogene. 2007;26(32):4617-26.

63. Kumar S, Dhiman M. Inflammasome activation and regulation during Helicobacter pylori pathogenesis. Microb Pathog. 2018;125:468-74.

64. Unemo M, Aspholm-Hurtig M, Ilver D, Bergstrom J, Boren T, Danielsson D, et al. The sialic acid binding SabA adhesin of Helicobacter pylori is essential for nonopsonic activation of human neutrophils. J Biol Chem. 2005;280(15):15390-7.

65. Blaser MJ, Perez-Perez GI, Kleanthous H, Cover TL, Peek $\mathrm{RM}$, Chyou PH, et al. Infection with Helicobacter pylori strains possessing cag A is associated with an increased risk of developing adenocarcinoma of the stomach. Cancer Res. 1995;55(10):2111-5.

66. Kronsteiner B, Bassaganya-Riera J, Philipson C, Viladomiu M, Carbo A, Abedi V, et al. Systems-wide analyses of mucosal immune responses to Helicobacter pylori at the interface between pathogenicity and symbiosis. Gut Microbes. 2016;7(1):3-21.

67. Gobert AP, Wilson KT. Polyamine- and NADPH-dependent generation of ROS during Helicobacter pylori infection: a blessing in disguise. Free Radic Biol Med. 2017;105:16-27.

68. Li X, Liu S, Luo J, Liu A, Tang S, Liu S, et al. Helicobacter pylori induces IL-1beta and IL-18 production in human monocytic cell line through activation of NLRP3 inflammasome via ROS signaling pathway. Pathog Dis. 2015. https://doi.org/10. 1093/femspd/ftu024.

69. Moreira AM, Pereira J, Melo S, Fernandes MS, Carneiro P, Seruca R, et al. The extracellular matrix: an accomplice in gastric cancer development and progression. Cells. 2020;9(2):394.

70. Bonnans C, Chou J, Werb Z. Remodelling the extracellular matrix in development and disease. Nat Rev Mol Cell Biol. 2014;15(12):786-801.

71. Kim SH, Turnbull J, Guimond S. Extracellular matrix and cell signalling: the dynamic cooperation of integrin, proteoglycan and growth factor receptor. J Endocrinol. 2011;209(2):139-51.

72. Rojas A, Araya P, Gonzalez I, Morales E. Gastric tumor microenvironment. Adv Exp Med Biol. 2020;1226:23-35.

73. Houghton J, Stoicov C, Nomura S, Rogers AB, Carlson J, Li H, et al. Gastric cancer originating from bone marrow-derived cells. Science. 2004;306(5701):1568-71.

74. Lee HJ, Song IC, Yun HJ, Jo DY, Kim S. CXC chemokines and chemokine receptors in gastric cancer: from basic findings towards therapeutic targeting. World J Gastroenterol. 2014;20(7):1681-93.

75. Lee HJ, Jo DY. The role of the CXCR4/CXCL12 axis and its clinical implications in gastric cancer. Histol Histopathol. 2012;27(9):1155-61.

76. Kopp HG, Ramos CA, Rafii S. Contribution of endothelial progenitors and proangiogenic hematopoietic cells to vascularization of tumor and ischemic tissue. Curr Opin Hematol. 2006;13(3):175-81.

77. Li B, Sharpe EE, Maupin AB, Teleron AA, Pyle AL, Carmeliet P, et al. VEGF and PIGF promote adult vasculogenesis by enhancing EPC recruitment and vessel formation at the site of tumor neovascularization. FASEB J. 2006;20(9):1495-7.

78. Direkze NC, Hodivala-Dilke K, Jeffery R, Hunt T, Poulsom R, Oukrif $\mathrm{D}$, et al. Bone marrow contribution to tumor-associated myofibroblasts and fibroblasts. Cancer Res. 2004;64(23):8492-5.
79. Kwa MQ, Herum KM, Brakebusch C. Cancer-associated fibroblasts: how do they contribute to metastasis? Clin Exp Metastasis. 2019;36(2):71-86.

80. Mishra P, Banerjee D, Ben-Baruch A. Chemokines at the crossroads of tumor-fibroblast interactions that promote malignancy. J Leukoc Biol. 2011;89(1):31-9.

81. Park SJ, Nakagawa T, Kitamura H, Atsumi T, Kamon H, Sawa S, et al. IL-6 regulates in vivo dendritic cell differentiation through STAT3 activation. J Immunol. 2004;173(6):3844-54.

82. Comito G, Giannoni E, Segura CP, Barcellos-de-Souza P, Raspollini MR, Baroni G, et al. Cancer-associated fibroblasts and M2-polarized macrophages synergize during prostate carcinoma progression. Oncogene. 2014;33(19):2423-31.

83. Harper J, Sainson RC. Regulation of the anti-tumour immune response by cancer-associated fibroblasts. Semin Cancer Biol. 2014;25:69-77.

84. Mantovani A, Schioppa T, Porta C, Allavena P, Sica A. Role of tumor-associated macrophages in tumor progression and invasion. Cancer Metastasis Rev. 2006;25(3):315-22.

85. Solinas G, Germano G, Mantovani A, Allavena P. Tumor-associated macrophages (TAM) as major players of the cancer-related inflammation. J Leukoc Biol. 2009;86(5):1065-73.

86. Prenen H, Mazzone M. Tumor-associated macrophages: a short compendium. Cell Mol Life Sci. 2019;76(8):1447-58.

87. Antonio N, Bonnelykke-Behrndtz ML, Ward LC, Collin J, Christensen IJ, Steiniche T, et al. The wound inflammatory response exacerbates growth of pre-neoplastic cells and progression to cancer. EMBO J. 2015;34(17):2219-36.

88. Wculek SK, Malanchi I. Neutrophils support lung colonization of metastasis-initiating breast cancer cells. Nature. 2015;528(7582):413-7.

89. El Rayes T, Catena R, Lee S, Stawowczyk M, Joshi N, Fischbach $\mathrm{C}$, et al. Lung inflammation promotes metastasis through neutrophil protease-mediated degradation of Tsp-1. Proc Natl Acad Sci USA. 2015;112(52):16000-5.

90. Casbon AJ, Reynaud D, Park C, Khuc E, Gan DD, Schepers $\mathrm{K}$, et al. Invasive breast cancer reprograms early myeloid differentiation in the bone marrow to generate immunosuppressive neutrophils. Proc Natl Acad Sci USA. 2015;112(6):E566-575.

91. Fridlender ZG, Sun J, Kim S, Kapoor V, Cheng G, Ling L, et al. Polarization of tumor-associated neutrophil phenotype by TGFbeta: "N1" versus "N2" TAN. Cancer Cell. 2009;16(3):183-94.

92. Zhang W, Gu J, Chen J, Zhang P, Ji R, Qian H, et al. Interaction with neutrophils promotes gastric cancer cell migration and invasion by inducing epithelial-mesenchymal transition. Oncol Rep. 2017;38(5):2959-66.

93. Li S, Cong X, Gao H, Lan X, Li Z, Wang W, et al. Correction to: tumor-associated neutrophils induce EMT by IL-17a to promote migration and invasion in gastric cancer cells. J Exp Clin Cancer Res. 2019;38(1):177.

94. Jiang YX, Yang SW, Li PA, Luo X, Li ZY, Hao YX, et al. The promotion of the transformation of quiescent gastric cancer stem cells by IL-17 and the underlying mechanisms. Oncogene. 2017;36(9):1256-64.

95. Dewayani A, Fauzia KA, Alfaray RI, Waskito LA, Doohan D, Rezkitha YAA, et al. The roles of IL-17, IL-21, and IL-23 in the Helicobacter pylori infection and gastrointestinal inflammation: a review. Toxins (Basel). 2021;13(5):315.

96. Ma HY, Liu XZ, Liang CM. Inflammatory microenvironment contributes to epithelial-mesenchymal transition in gastric cancer. World J Gastroenterol. 2016;22(29):6619-28.

97. Prudova A, Gocheva V, Auf dem Keller U, Eckhard U, Olson OC, Akkari L, et al. TAILS N-terminomics and proteomics show protein degradation dominates over proteolytic processing by cathepsins in pancreatic tumors. Cell Rep. 2016;16(6):1762-73. 
98. Olson OC, Joyce JA. Cysteine cathepsin proteases: regulators of cancer progression and therapeutic response. Nat Rev Cancer. 2015;15(12):712-29.

99. Sobotic B, Vizovisek M, Vidmar R, Van Damme P, Gocheva V, Joyce JA, et al. Proteomic identification of cysteine cathepsin substrates shed from the surface of cancer cells. Mol Cell Proteom. 2015;14(8):2213-28.

100. Nakao S, Zandi S, Sun D, Hafezi-Moghadam A. Cathepsin B-mediated CD18 shedding regulates leukocyte recruitment from angiogenic vessels. FASEB J. 2018;32(1):143-54.

101. Sevenich L, Bowman RL, Mason SD, Quail DF, Rapaport F, Elie BT, et al. Analysis of tumour- and stroma-supplied proteolytic networks reveals a brain-metastasis-promoting role for cathepsin S. Nat Cell Biol. 2014;16(9):876-88.

102. Rozhin J, Sameni M, Ziegler G, Sloane BF. Pericellular $\mathrm{pH}$ affects distribution and secretion of cathepsin B in malignant cells. Cancer Res. 1994;54(24):6517-25.

103. Kramer L, Turk D, Turk B. The future of cysteine cathepsins in disease management. Trends Pharmacol Sci. 2017;38(10):873-98.

104. Reiser J, Adair B, Reinheckel T. Specialized roles for cysteine cathepsins in health and disease. J Clin Invest. 2010;120(10):3421-31.

105. Sukhova GK, Shi GP, Simon DI, Chapman HA, Libby P. Expression of the elastolytic cathepsins $\mathrm{S}$ and $\mathrm{K}$ in human atheroma and regulation of their production in smooth muscle cells. J Clin Invest. 1998;102(3):576-83.

106. Jordans S, Jenko-Kokalj S, Kuhl NM, Tedelind S, Sendt W, Bromme D, et al. Monitoring compartment-specific substrate cleavage by cathepsins $\mathrm{B}, \mathrm{K}, \mathrm{L}$, and $\mathrm{S}$ at physiological $\mathrm{pH}$ and redox conditions. BMC Biochem. 2009;10:23.

107. Godat E, Herve-Grvepinet V, Veillard F, Lecaille F, Belghazi M, Bromme D, et al. Regulation of cathepsin K activity by hydrogen peroxide. Biol Chem. 2008;389(8):1123-6.

108. Galjart NJ, Gillemans N, Harris A, van der Horst GT, Verheijen FW, Galjaard H, et al. Expression of cDNA encoding the human "protective protein" associated with lysosomal beta-galactosidase and neuraminidase: homology to yeast proteases. Cell. 1988;54(6):755-64.

109. Kozlowski L, Wojtukiewicz MZ, Ostrowska H. Cathepsin A activity in primary and metastatic human melanocytic tumors. Arch Dermatol Res. 2000;292(2-3):68-71.

110. Chan SJ, San Segundo B, McCormick MB, Steiner DF. Nucleotide and predicted amino acid sequences of cloned human and mouse preprocathepsin B cDNAs. Proc Natl Acad Sci USA. 1986;83(20):7721-5.

111. Kleer CG, Bloushtain-Qimron N, Chen YH, Carrasco D, Hu M, Yao J, et al. Epithelial and stromal cathepsin K and CXCL14 expression in breast tumor progression. Clin Cancer Res. 2008;14(17):5357-67.

112. Faust PL, Kornfeld S, Chirgwin JM. Cloning and sequence analysis of cDNA for human cathepsin D. Proc Natl Acad Sci USA. 1985;82(15):4910-4.

113. Pranjol MZI, Gutowski NJ, Hannemann M, Whatmore JL. Cathepsin $\mathrm{L}$ induces proangiogenic changes in human omental microvascular endothelial cells via activation of the ERK1/2 pathway. Curr Cancer Drug Targets. 2018;19:231-42.

114. Fuchs R, Machleidt W, Gassen HG. Molecular cloning and sequencing of a cDNA coding for mature human kidney cathepsin H. Biol Chem Hoppe Seyler. 1988;369(6):469-75.

115. Krueger S, Kalinski T, Hundertmark T, Wex T, Kuster D, Peitz $\mathrm{U}$, et al. Up-regulation of cathepsin $\mathrm{X}$ in Helicobacter pylori gastritis and gastric cancer. J Pathol. 2005;207(1):32-42.

116. Inaoka $\mathrm{T}$, Bilbe $\mathrm{G}$, Ishibashi $\mathrm{O}$, Tezuka $\mathrm{K}$, Kumegawa $\mathrm{M}$, Kokubo T. Molecular cloning of human cDNA for cathepsin
$\mathrm{K}$ : novel cysteine proteinase predominantly expressed in bone. Biochem Biophys Res Commun. 1995;206(1):89-96.

117. Verbovsek U, Van Noorden CJ, Lah TT. Complexity of cancer protease biology: Cathepsin K expression and function in cancer progression. Semin Cancer Biol. 2015;35:71-84.

118. Joseph LJ, Chang LC, Stamenkovich D, Sukhatme VP. Complete nucleotide and deduced amino acid sequences of human and murine preprocathepsin L. An abundant transcript induced by transformation of fibroblasts. J Clin Invest. 1988;81(5):1621-9.

119. Sudhan DR, Pampo C, Rice L, Siemann DW. Cathepsin L inactivation leads to multimodal inhibition of prostate cancer cell dissemination in a preclinical bone metastasis model. Int J Cancer. 2016;138(11):2665-77.

120. Sudhan DR, Rabaglino MB, Wood CE, Siemann DW. Cathepsin $\mathrm{L}$ in tumor angiogenesis and its therapeutic intervention by the small molecule inhibitor KGP94. Clin Exp Metastasis. 2016;33(5):461-73.

121. Shi GP, Munger JS, Meara JP, Rich DH, Chapman HA. Molecular cloning and expression of human alveolar macrophage cathepsin S, an elastinolytic cysteine protease. J Biol Chem. 1992;267(11):7258-62.

122. Wilkinson RD, Williams R, Scott CJ, Burden RE. Cathepsin S: therapeutic, diagnostic, and prognostic potential. Biol Chem. 2015;396(8):867-82.

123. Nagler DK, Zhang R, Tam W, Sulea T, Purisima EO, Menard R. Human cathepsin X: a cysteine protease with unique carboxypeptidase activity. Biochemistry. 1999;38(39):12648-54.

124. Nagler DK, Kruger S, Kellner A, Ziomek E, Menard R, Buhtz $\mathrm{P}$, et al. Up-regulation of cathepsin $\mathrm{X}$ in prostate cancer and prostatic intraepithelial neoplasia. Prostate. 2004;60(2):109-19.

125. Wang J, Chen L, Li Y, Guan XY. Overexpression of cathepsin $\mathrm{Z}$ contributes to tumor metastasis by inducing epithelial-mesenchymal transition in hepatocellular carcinoma. PLoS ONE. 2011;6(9):e24967.

126. Hashimoto Y, Kondo C, Katunuma N. An active $32-\mathrm{kDa}$ Cathepsin L is secreted directly from HT 1080 fibrosarcoma cells and not via lysosomal exocytosis. PLoS ONE. 2015;10(12):e0145067.

127. Rodriguez A, Webster P, Ortego J, Andrews NW. Lysosomes behave as $\mathrm{Ca} 2+-$-regulated exocytic vesicles in fibroblasts and epithelial cells. J Cell Biol. 1997;137(1):93-104.

128. Caglic D, Repnik U, Jedeszko C, Kosec G, Miniejew C, Kindermann M, et al. The proinflammatory cytokines interleukin1 alpha and tumor necrosis factor alpha promote the expression and secretion of proteolytically active cathepsin $\mathrm{S}$ from human chondrocytes. Biol Chem. 2013;394(2):307-16.

129. Mohamed MM, Cavallo-Medved D, Rudy D, Anbalagan A, Moin $\mathrm{K}$, Sloane BF. Interleukin-6 increases expression and secretion of cathepsin B by breast tumor-associated monocytes. Cell Physiol Biochem. 2010;25(2-3):315-24.

130. Konttinen YT, Mandelin J, Li TF, Salo J, Lassus J, Liljestrom M, et al. Acidic cysteine endoproteinase cathepsin $\mathrm{K}$ in the degeneration of the superficial articular hyaline cartilage in osteoarthritis. Arthritis Rheum. 2002;46(4):953-60.

131. Mohamed MM, Sloane BF. Cysteine cathepsins: multifunctional enzymes in cancer. Nat Rev Cancer. 2006;6(10):764-75.

132. Naghavi M, John R, Naguib S, Siadaty MS, Grasu R, Kurian $\mathrm{KC}$, et al. pH Heterogeneity of human and rabbit atherosclerotic plaques; a new insight into detection of vulnerable plaque. Atherosclerosis. 2002;164(1):27-35.

133. Ichinose S, Usuda J, Hirata T, Inoue T, Ohtani K, Maehara S, et al. Lysosomal cathepsin initiates apoptosis, which is regulated by photodamage to $\mathrm{Bcl}-2$ at mitochondria in photodynamic therapy using a novel photosensitizer, ATX-s10 (Na). Int J Oncol. 2006;29(2):349-55. 
134. Chwieralski CE, Welte T, Buhling F. Cathepsin-regulated apoptosis. Apoptosis. 2006;11(2):143-9.

135. Turk B, Dolenc I, Turk V, Bieth JG. Kinetics of the pHinduced inactivation of human cathepsin L. Biochemistry. 1993;32(1):375-80.

136. Turk B, Bieth JG, Bjork I, Dolenc I, Turk D, Cimerman N, et al. Regulation of the activity of lysosomal cysteine proteinases by $\mathrm{pH}$-induced inactivation and/or endogenous protein inhibitors, cystatins. Biol Chem Hoppe Seyler. 1995;376(4):225-30.

137. Caglic D, Pungercar JR, Pejler G, Turk V, Turk B. Glycosaminoglycans facilitate procathepsin B activation through disruption of propeptide-mature enzyme interactions. J Biol Chem. 2007;282(45):33076-85.

138. Li Z, Yasuda Y, Li W, Bogyo M, Katz N, Gordon RE, et al. Regulation of collagenase activities of human cathepsins by glycosaminoglycans. J Biol Chem. 2004;279(7):5470-9.

139. Ruettger A, Schueler S, Mollenhauer JA, Wiederanders B. Cathepsins B, K, and $\mathrm{L}$ are regulated by a defined collagen type II peptide via activation of classical protein kinase C and p38 MAP kinase in articular chondrocytes. J Biol Chem. 2008;283(2):1043-51.

140. Gocheva V, Zeng W, Ke D, Klimstra D, Reinheckel T, Peters C, et al. Distinct roles for cysteine cathepsin genes in multistage tumorigenesis. Genes Dev. 2006;20(5):543-56.

141. Willumsen N, Bager CL, Leeming DJ, Bay-Jensen AC, Karsdal MA. Nidogen-1 degraded by cathepsin $\mathrm{S}$ can be quantified in serum and is associated with non-small cell lung cancer. Neoplasia. 2017;19(4):271-8.

142. Wang B, Sun J, Kitamoto S, Yang M, Grubb A, Chapman HA, et al. Cathepsin S controls angiogenesis and tumor growth via matrix-derived angiogenic factors. J Biol Chem. 2006;281(9):6020-9.

143. Guinec N, Dalet-Fumeron V, Pagano M. "In vitro" study of basement membrane degradation by the cysteine proteinases, cathepsins B, B-like and L. Digestion of collagen IV, laminin, fibronectin, and release of gelatinase activities from basement membrane fibronectin. Biol Chem Hoppe Seyler. 1993;374(12):1135-46.

144. Mai J, Sameni M, Mikkelsen T, Sloane BF. Degradation of extracellular matrix protein tenascin-C by cathepsin B: an interaction involved in the progression of gliomas. Biol Chem. 2002;383(9):1407-13.

145. Felbor U, Dreier L, Bryant RA, Ploegh HL, Olsen BR, Mothes W. Secreted cathepsin L generates endostatin from collagen XVIII. EMBO J. 2000;19(6):1187-94.

146. Veillard F, Saidi A, Burden RE, Scott CJ, Gillet L, Lecaille F, et al. Cysteine cathepsins $\mathrm{S}$ and L modulate anti-angiogenic activities of human endostatin. J Biol Chem. 2011;286(43):37158-67.

147. Gineyts E, Bonnet N, Bertholon C, Millet M, Pagnon-Minot A, Borel $\mathrm{O}$, et al. The C-terminal intact forms of periostin (iPTN) are surrogate markers for osteolytic lesions in experimental breast cancer bone metastasis. Calcif Tissue Int. 2018;103(5):567-80.

148. Podgorski I, Linebaugh BE, Koblinski JE, Rudy DL, Herroon MK, Olive MB, et al. Bone marrow-derived cathepsin K cleaves SPARC in bone metastasis. Am J Pathol. 2009;175(3):1255-69.

149. Liu CL, Guo J, Zhang X, Sukhova GK, Libby P, Shi GP. Cysteine protease cathepsins in cardiovascular disease: from basic research to clinical trials. Nat Rev Cardiol. 2018;15(6):351-70.

150. Saini MG, Bix GJ. Oxygen-glucose deprivation (OGD) and interleukin-1 (IL-1) differentially modulate cathepsin B/L mediated generation of neuroprotective perlecan LG3 by neurons. Brain Res. 2012;1438:65-74.

151. Yasuda Y, Li Z, Greenbaum D, Bogyo M, Weber E, Bromme D. Cathepsin V, a novel and potent elastolytic activity expressed in activated macrophages. J Biol Chem. 2004;279(35):36761-70.
152. Gocheva V, Joyce JA. Cysteine cathepsins and the cutting edge of cancer invasion. Cell Cycle. 2007;6(1):60-4.

153. Vizovisek M, Fonovic M, Turk B. Cysteine cathepsins in extracellular matrix remodeling: extracellular matrix degradation and beyond. Matrix Biol. 2019;75-76:141-59.

154. Fonovic M, Turk B. Cysteine cathepsins and extracellular matrix degradation. Biochim Biophys Acta. 2014;1840(8):2560-70.

155. Repnik U, Starr AE, Overall CM, Turk B. Cysteine cathepsins activate ELR chemokines and inactivate non-ELR chemokines. J Biol Chem. 2015;290(22):13800-11.

156. Ainscough JS, Macleod T, McGonagle D, Brakefield R, Baron $\mathrm{JM}$, Alase A, et al. Cathepsin $\mathrm{S}$ is the major activator of the psoriasis-associated proinflammatory cytokine IL-36gamma. Proc Natl Acad Sci USA. 2017;114(13):E2748-57.

157. Breznik B, Motaln H, Lah Turnsek T. Proteases and cytokines as mediators of interactions between cancer and stromal cells in tumours. Biol Chem. 2017;398(7):709-19.

158. Ohashi K, Naruto M, Nakaki T, Sano E. Identification of interleukin-8 converting enzyme as cathepsin L. Biochim Biophys Acta. 2003;1649(1):30-9.

159. Hira VV, Verbovsek U, Breznik B, Srdic M, Novinec M, Kakar $\mathrm{H}$, et al. Cathepsin K cleavage of SDF-1alpha inhibits its chemotactic activity towards glioblastoma stem-like cells. Biochim Biophys Acta Mol Cell Res. 2017;1864(3):594-603.

160. Clark AK, Yip PK, Malcangio M. The liberation of fractalkine in the dorsal horn requires microglial cathepsin S. J Neurosci. 2009;29(21):6945-54.

161. Allgayer H, Babic R, Grutzner KU, Beyer BC, Tarabichi A, Wilhelm Schildberg F, et al. An immunohistochemical assessment of cathepsin D in gastric carcinoma: its impact on clinical prognosis. Cancer. 1997;80(2):179-87.

162. Yang Y, Lim SK, Choong LY, Lee H, Chen Y, Chong PK, et al. Cathepsin $\mathrm{S}$ mediates gastric cancer cell migration and invasion via a putative network of metastasis-associated proteins. J Proteome Res. 2010;9(9):4767-78.

163. Liu WL, Liu D, Cheng K, Liu YJ, Xing S, Chi PD, et al. Evaluating the diagnostic and prognostic value of circulating cathepsin S in gastric cancer. Oncotarget. 2016;7(19):28124-38.

164. Engevik AC, Feng R, Choi E, White S, Bertaux-Skeirik N, Li J, et al. The development of spasmolytic polypeptide/ TFF2-expressing metaplasia (SPEM) during gastric repair is absent in the aged stomach. Cell Mol Gastroenterol Hepatol. 2016;2(5):605-24.

165. Shalhoub V, Faust J, Boyle WJ, Dunstan CR, Kelley M, Kaufman $\mathrm{S}$, et al. Osteoprotegerin and osteoprotegerin ligand effects on osteoclast formation from human peripheral blood mononuclear cell precursors. J Cell Biochem. 1999;72(2):251-61.

166. Krueger S, Bernhardt A, Kalinski T, Baldensperger M, Zeh M, Teller A, et al. Induction of premalignant host responses by cathepsin x/z-deficiency in Helicobacter pylori-infected mice. PLoS ONE. 2013;8(7):e70242.

167. Buhling F, Peitz U, Kruger S, Kuster D, Vieth M, Gebert I, et al. Cathepsins K, L, B, X and W are differentially expressed in normal and chronically inflamed gastric mucosa. Biol Chem. 2004;385(5):439-45.

168. Kuester D, Vieth M, Peitz U, Kahl S, Stolte M, Roessner A, et al. Upregulation of cathepsin W-expressing T cells is specific for autoimmune atrophic gastritis compared to other types of chronic gastritis. World J Gastroenterol. 2005;11(38):5951-7.

169. Farinati F, Herszenyi L, Plebani M, Carraro P, De Paoli M, Cardin R, et al. Increased levels of cathepsin B and L, urokinase-type plasminogen activator and its inhibitor type- 1 as an early event in gastric carcinogenesis. Carcinogenesis. 1996;17(12):2581-7.

170. Lin CK, Lai KH, Lo GH, Cheng JS, Hsu PI, Mok KT, et al. Cathepsin $\mathrm{E}$ and subtypes of intestinal metaplasia in 
carcinogenesis of the human stomach. Zhonghua Yi Xue Za Zhi (Taipei). 2001;64(6):331-6.

171. Konno-Shimizu M, Yamamichi N, Inada K, Kageyama-Yahara $\mathrm{N}$, Shiogama K, Takahashi Y, et al. Cathepsin E is a marker of gastric differentiation and signet-ring cell carcinoma of stomach: a novel suggestion on gastric tumorigenesis. PLoS ONE. 2013;8(2):e56766.

172. Ebert MP, Kruger S, Fogeron ML, Lamer S, Chen J, Pross M, et al. Overexpression of cathepsin B in gastric cancer identified by proteome analysis. Proteomics. 2005;5(6):1693-704.

173. Watanabe M, Higashi T, Hashimoto M, Tomoda I, Tominaga S, Hashimoto N, et al. Elevation of tissue cathepsin B and L activities in gastric cancer. Hepatogastroenterology. 1987;34(3):120-2.

174. Watanabe M, Higashi T, Watanabe A, Osawa T, Sato Y, Kimura $\mathrm{Y}$, et al. Cathepsin $\mathrm{B}$ and $\mathrm{L}$ activities in gastric cancer tissue: correlation with histological findings. Biochem Med Metab Biol. 1989;42(1):21-9.

175. Gounaris E, Tung CH, Restaino C, Maehr R, Kohler R, Joyce JA, et al. Live imaging of cysteine-cathepsin activity reveals dynamics of focal inflammation, angiogenesis, and polyp growth. PLoS ONE. 2008;3(8):e2916.

176. Ha SD, Martins A, Khazaie K, Han J, Chan BM, Kim SO. Cathepsin B is involved in the trafficking of TNF-alpha-containing vesicles to the plasma membrane in macrophages. $\mathrm{J}$ Immunol. 2008;181(1):690-7.

177. Herroon MK, Rajagurubandara E, Rudy DL, Chalasani A, Hardaway AL, Podgorski I. Macrophage cathepsin K promotes prostate tumor progression in bone. Oncogene. 2013;32(12):1580-93.

178. Wilkinson RD, Magorrian SM, Williams R, Young A, Small $\mathrm{DM}$, Scott CJ, et al. CCL2 is transcriptionally controlled by the lysosomal protease cathepsin S in a CD74-dependent manner. Oncotarget. 2015;6(30):29725-39.

179. Hayakawa Y, Fox JG, Wang TC. The origins of gastric cancer from gastric stem cells: lessons from mouse models. Cell Mol Gastroenterol Hepatol. 2017;3(3):331-8.

180. Ugel S, De Sanctis F, Mandruzzato S, Bronte V. Tumorinduced myeloid deviation: when myeloid-derived suppressor cells meet tumor-associated macrophages. J Clin Invest. 2015;125(9):3365-76.

181. Salpeter SJ, Pozniak Y, Merquiol E, Ben-Nun Y, Geiger T, Blum G. A novel cysteine cathepsin inhibitor yields macrophage cell death and mammary tumor regression. Oncogene. 2015;34(50):6066-78.

182. Yang M, Liu J, Shao J, Qin Y, Ji Q, Zhang X, et al. Cathepsin $\mathrm{S}$-mediated autophagic flux in tumor-associated macrophages accelerate tumor development by promoting M2 polarization. Mol Cancer. 2014;13:43.

183. Li R, Zhou R, Wang H, Li W, Pan M, Yao X, et al. Gut microbiota-stimulated cathepsin K secretion mediates TLR4-dependent M2 macrophage polarization and promotes tumor metastasis in colorectal cancer. Cell Death Differ. 2019;26(11):2447-63.

184. Vizovisek M, Vidmar R, Van Quickelberghe E, Impens F, Andjelkovic U, Sobotic B, et al. Fast profiling of protease specificity reveals similar substrate specificities for cathepsins $\mathrm{K}, \mathrm{L}$ and S. Proteomics. 2015;15(14):2479-90.

185. Biniossek ML, Nagler DK, Becker-Pauly C, Schilling O. Proteomic identification of protease cleavage sites characterizes prime and non-prime specificity of cysteine cathepsins B, L, and S. J Proteome Res. 2011;10(12):5363-73.

186. Ewald SE, Engel A, Lee J, Wang M, Bogyo M, Barton GM. Nucleic acid recognition by Toll-like receptors is coupled to stepwise processing by cathepsins and asparagine endopeptidase. J Exp Med. 2011;208(4):643-51.

187. Yao RR, Li JH, Zhang R, Chen RX, Wang YH. M2-polarized tumor-associated macrophages facilitated migration and epithelial-mesenchymal transition of HCC cells via the TLR4/ STAT3 signaling pathway. World J Surg Oncol. 2018;16(1):9.

188. Pham CT, Ivanovich JL, Raptis SZ, Zehnbauer B, Ley TJ. Papillon-Lefevre syndrome: correlating the molecular, cellular, and clinical consequences of cathepsin C/dipeptidyl peptidase I deficiency in humans. J Immunol. 2004;173(12):7277-81.

189. Cirman T, Oresic K, Mazovec GD, Turk V, Reed JC, Myers RM, et al. Selective disruption of lysosomes in HeLa cells triggers apoptosis mediated by cleavage of Bid by multiple papain-like lysosomal cathepsins. J Biol Chem. 2004;279(5):3578-87.

190. Conus S, Perozzo R, Reinheckel T, Peters C, Scapozza L, Yousefi $\mathrm{S}$, et al. Caspase-8 is activated by cathepsin D initiating neutrophil apoptosis during the resolution of inflammation. J Exp Med. 2008;205(3):685-98.

191. Sukhova GK, Zhang Y, Pan JH, Wada Y, Yamamoto T, Naito M, et al. Deficiency of cathepsin $\mathrm{S}$ reduces atherosclerosis in LDL receptor-deficient mice. J Clin Invest. 2003;111(6):897-906.

192. Sina C, Lipinski S, Gavrilova O, Aden K, Rehman A, Till A, et al. Extracellular cathepsin K exerts antimicrobial activity and is protective against chronic intestinal inflammation in mice. Gut. 2013;62(4):520-30.

193. Houghton AN, Guevara-Patino JA. Immune recognition of self in immunity against cancer. J Clin Invest. 2004;114(4):468-71.

194. Freeman GJ, Long AJ, Iwai Y, Bourque K, Chernova T, Nishimura $\mathrm{H}$, et al. Engagement of the PD-1 immunoinhibitory receptor by a novel B7 family member leads to negative regulation of lymphocyte activation. J Exp Med. 2000;192(7):1027-34.

195. Wang J, Yuan R, Song W, Sun J, Liu D, Li Z. PD-1, PD-L1 (B7H1) and tumor-site immune modulation therapy: the historical perspective. J Hematol Oncol. 2017;10(1):34.

196. Lenschow DJ, Sperling AI, Cooke MP, Freeman G, Rhee L, Decker DC, et al. Differential up-regulation of the B7-1 and B7-2 costimulatory molecules after Ig receptor engagement by antigen. J Immunol. 1994;153(5):1990-7.

197. Anderson AC, Joller N, Kuchroo VK. Lag-3, Tim-3, and TIGIT: co-inhibitory receptors with specialized functions in immune regulation. Immunity. 2016;44(5):989-1004.

198. Triebel F. LAG-3: a regulator of T-cell and DC responses and its use in therapeutic vaccination. Trends Immunol. 2003;24(12):619-22.

199. Xu M, Li J, Gulfo JV, Von Hofe E, Humphreys RE. MHC class II allosteric site drugs: new immunotherapeutics for malignant, infectious and autoimmune diseases. Scand J Immunol. 2001;54(1-2):39-44.

200. Honey K, Rudensky AY. Lysosomal cysteine proteases regulate antigen presentation. Nat Rev Immunol. 2003;3(6):472-82.

201. Xu M, Capraro GA, Daibata M, Reyes VE, Humphreys RE. Cathepsin B cleavage and release of invariant chain from MHC class II molecules follow a staged pattern. Mol Immunol. 1994;31(10):723-31.

202. Burster T, Macmillan H, Hou T, Schilling J, Truong P, Boehm $\mathrm{BO}$, et al. Masking of a cathepsin $\mathrm{G}$ cleavage site in vivo contributes to the proteolytic resistance of major histocompatibility complex class II molecules. Immunology. 2010;130(3):436-46.

203. Kitamura H, Kamon H, Sawa S, Park SJ, Katunuma N, Ishihara $\mathrm{K}$, et al. IL-6-STAT3 controls intracellular MHC class II alphabeta dimer level through cathepsin $\mathrm{S}$ activity in dendritic cells. Immunity. 2005;23(5):491-502.

204. Martino S, Tiribuzi R, Ciraci E, Makrypidi G, D’Angelo F, di Girolamo I, et al. Coordinated involvement of cathepsins S, D and cystatin $\mathrm{C}$ in the commitment of hematopoietic stem cells to dendritic cells. Int J Biochem Cell Biol. 2011;43(5):775-83.

205. Pradere JP, Dapito DH, Schwabe RF. The Yin and Yang of Tolllike receptors in cancer. Oncogene. 2014;33(27):3485-95. 
206. Kaur K, Nanut MP, Ko MW, Safaie T, Kos J, Jewett A. Natural killer cells target and differentiate cancer stem-like cells/undifferentiated tumors: strategies to optimize their growth and expansion for effective cancer immunotherapy. Curr Opin Immunol. 2018;51:170-80.

207. Konjar S, Sutton VR, Hoves S, Repnik U, Yagita H, Reinheckel $\mathrm{T}$, et al. Human and mouse perforin are processed in part through cleavage by the lysosomal cysteine proteinase cathepsin $\mathrm{L}$. Immunology. 2010;131(2):257-67.

208. D'Angelo ME, Bird PI, Peters C, Reinheckel T, Trapani JA, Sutton VR. Cathepsin $\mathrm{H}$ is an additional convertase of pro-granzyme B. J Biol Chem. 2010;285(27):20514-9.

209. Magister S, Tseng HC, Bui VT, Kos J, Jewett A. Regulation of split anergy in natural killer cells by inhibition of cathepsins $\mathrm{C}$ and $\mathrm{H}$ and cystatin F. Oncotarget. 2015;6(26):22310-27.

210. Perisic Nanut M, Sabotic J, Svajger U, Jewett A, Kos J. Cystatin $\mathrm{F}$ affects natural killer cell cytotoxicity. Front Immunol. 2017;8:1459.

211. Prunk M, Nanut MP, Sabotic J, Svajger U, Kos J. Increased cystatin $\mathrm{F}$ levels correlate with decreased cytotoxicity of cytotoxic T cells. Radiol Oncol. 2019;53(1):57-68.

212. Ford AC, Forman D, Hunt R, Yuan Y, Moayyedi P. Helicobacter pylori eradication for the prevention of gastric neoplasia. Cochrane Database Syst Rev. 2015;7:CD005583.

213. Lee YC, Chiang TH, Chou CK, Tu YK, Liao WC, Wu MS, et al. Association between Helicobacter pylori eradication and gastric cancer incidence: a systematic review and meta-analysis. Gastroenterology. 2016;150(5):1113-1124 e1115.

214. Yang JC, Lin CJ. CYP2C19 genotypes in the pharmacokinetics/ pharmacodynamics of proton pump inhibitor-based therapy of Helicobacter pylori infection. Expert Opin Drug Metab Toxicol. 2010;6(1):29-41.

215. Malfertheiner P, Megraud F, O'Morain C, Bazzoli F, El-Omar E, Graham D, et al. Current concepts in the management of Helicobacter pylori infection: the Maastricht III Consensus Report. Gut. 2007;56(6):772-81.

216. Japanese Gastric Cancer Association. Japanese classification of gastric carcinoma: 3rd English edition. Gastric Cancer. 2011;14(2):101-12. https://doi.org/10.1007/s10120-011-0041-5. PMID: 21573743.

217. Schuhmacher C, Gretschel S, Lordick F, Reichardt P, Hohenberger W, Eisenberger CF, et al. Neoadjuvant chemotherapy compared with surgery alone for locally advanced cancer of the stomach and cardia: European Organisation for Research and Treatment of Cancer randomized trial 40954. J Clin Oncol. 2010;28(35):5210-8.

218. Lordick F. Chemotherapy for resectable microsatellite instabilityhigh gastric cancer? Lancet Oncol. 2020;21(2):203.

219. Smyth EC, Nilsson M, Grabsch HI, van Grieken NC, Lordick F. Gastric cancer. Lancet. 2020;396(10251):635-48.

220. Song Z, Wu Y, Yang J, Yang D, Fang X. Progress in the treatment of advanced gastric cancer. Tumour Biol. 2017;39(7):1010428317714626.

221. Li Y, Wang C, Xu M, Kong C, Qu A, Zhang M, et al. Preoperative NLR for predicting survival rate after radical resection combined with adjuvant immunotherapy with CIK and postoperative chemotherapy in gastric cancer. J Cancer Res Clin Oncol. 2017;143(5):861-71.

222. de Guillebon E, Roussille P, Frouin E, Tougeron D. Anti program death-1/anti program death-ligand 1 in digestive cancers. World J Gastrointest Oncol. 2015;7(8):95-101.

223. Shitara K, Iwata H, Takahashi S, Tamura K, Park H, Modi S, et al. Trastuzumab deruxtecan (DS-8201a) in patients with advanced HER2-positive gastric cancer: a dose-expansion, phase 1 study. Lancet Oncol. 2019;20(6):827-36.
224. Shitara K, Bang YJ, Iwasa S, Sugimoto N, Ryu MH, Sakai D, et al. Trastuzumab deruxtecan in previously treated HER2-positive gastric cancer. N Engl J Med. 2020;382(25):2419-30.

225. Mishima S, Shitara K. Trastuzumab deruxtecan for the treatment of HER2-positive gastric cancer. Expert Opin Biol Ther. 2021;21(7):825-30.

226. Group G, Paoletti X, Oba K, Burzykowski T, Michiels S, Ohashi $\mathrm{Y}$, et al. Benefit of adjuvant chemotherapy for resectable gastric cancer: a meta-analysis. JAMA. 2010;303(17):1729-37.

227. Smyth EC, Verheij M, Allum W, Cunningham D, Cervantes A, Arnold D, et al. Gastric cancer: ESMO Clinical Practice Guidelines for diagnosis, treatment and follow-up. Ann Oncol. 2016;27(suppl 5):v38-49.

228. Muro K, Van Cutsem E, Narita Y, Pentheroudakis G, Baba E, Li J, et al. Pan-Asian adapted ESMO Clinical Practice Guidelines for the management of patients with metastatic gastric cancer: a JSMO-ESMO initiative endorsed by CSCO, KSMO, MOS, SSO and TOS. Ann Oncol. 2019;30(1):19-33.

229. Ajani JA, D'Amico TA, Almhanna K, Bentrem DJ, Chao J, Das P, et al. Gastric cancer, version 3.2016, NCCN clinical practice guidelines in oncology. J Natl Compr Canc Netw. 2016;14(10):1286-312.

230. Guimbaud R, Louvet C, Ries P, Ychou M, Maillard E, Andre T, et al. Prospective, randomized, multicenter, phase III study of fluorouracil, leucovorin, and irinotecan versus epirubicin, cisplatin, and capecitabine in advanced gastric adenocarcinoma: a French intergroup (Federation Francophone de Cancerologie Digestive, Federation Nationale des Centres de Lutte Contre le Cancer, and Groupe Cooperateur Multidisciplinaire en Oncologie) study. J Clin Oncol. 2014;32(31):3520-6.

231. Jung CP, Motwani MV, Schwartz GK. Flavopiridol increases sensitization to gemcitabine in human gastrointestinal cancer cell lines and correlates with down-regulation of ribonucleotide reductase M2 subunit. Clin Cancer Res. 2001;7(8):2527-36.

232. Motwani M, Rizzo C, Sirotnak F, She Y, Schwartz GK. Flavopiridol enhances the effect of docetaxel in vitro and in vivo in human gastric cancer cells. Mol Cancer Ther. 2003;2(6):549-55.

233. Wilke H, Muro K, Van Cutsem E, Oh SC, Bodoky G, Shimada $\mathrm{Y}$, et al. Ramucirumab plus paclitaxel versus placebo plus paclitaxel in patients with previously treated advanced gastric or gastro-oesophageal junction adenocarcinoma (RAINBOW): a double-blind, randomised phase 3 trial. Lancet Oncol. 2014;15(11):1224-35.

234. Sun W, Powell M, O’Dwyer PJ, Catalano P, Ansari RH, Benson AB 3rd. Phase II study of sorafenib in combination with docetaxel and cisplatin in the treatment of metastatic or advanced gastric and gastroesophageal junction adenocarcinoma: ECOG 5203. J Clin Oncol. 2010;28(18):2947-51.

235. Amantini C, Morelli MB, Santoni M, Soriani A, Cardinali C, Farfariello V, et al. Sorafenib induces cathepsin B-mediated apoptosis of bladder cancer cells by regulating the Akt/PTEN pathway. The Akt inhibitor, perifosine, enhances the sorafenibinduced cytotoxicity against bladder cancer cells. Oncoscience. 2015;2(4):395-409.

236. Shah MA, Ramanathan RK, Ilson DH, Levnor A, D'Adamo D, O'Reilly E, et al. Multicenter phase II study of irinotecan, cisplatin, and bevacizumab in patients with metastatic gastric or gastroesophageal junction adenocarcinoma. J Clin Oncol. 2006;24(33):5201-6.

237. Bagheri A, Soheili ZS, Ahmadieh H, Samiei S, Sheibani N, Astaneh SD, et al. Simultaneous application of bevacizumab and antiCTGF antibody effectively suppresses proangiogenic and profibrotic factors in human RPE cells. Mol Vis. 2015;21:378-90.

238. Chen Q, Shen L, Chen C, He H, Fu Y, Xu L, et al. Cetuximab combined with cisplatin improves the prognosis of gastric cancer 
patients and its effect on P38 MAPK expression. J BUON. 2019;24(6):2490-8.

239. Tebbutt NC, Price TJ, Ferraro DA, Wong N, Veillard AS, Hall M, et al. Panitumumab added to docetaxel, cisplatin and fluoropyrimidine in oesophagogastric cancer: ATTAX3 phase II trial. Br J Cancer. 2016;114(5):505-9.

240. Quintero Aldana G, Salgado M, Candamio S, Mendez JC, Jorge $\mathrm{M}$, Reboredo M, et al. First-line panitumumab plus docetaxel and cisplatin in advanced gastric and gastro-oesophageal junction adenocarcinoma: results of a phase II trial. Clin Transl Oncol. 2020;22(4):495-502.

241. Du F, Zheng Z, Shi S, Jiang Z, Qu T, Yuan X, et al. S-1 and cisplatin with or without nimotuzumab for patients with untreated unresectable or metastatic gastric cancer: a randomized, openlabel phase 2 trial. Medicine (Baltimore). 2015;94(23):e958.

242. Xu CD. Clinical study of nimotuzumab combined with chemotherapy in the treatment of late stage gastric cancer. Asian Pac J Cancer Prev. 2014;15(23):10273-6.

243. Stein A, Moehler M, Trojan J, Goekkurt E, Vogel A. Immunooncology in GI tumours: clinical evidence and emerging trials of PD-1/PD-L1 antagonists. Crit Rev Oncol Hematol. 2018;130:13-26.

244. Roviello G, D’Angelo A, Generali D, Pittacolo M, Ganzinelli $\mathrm{M}$, Iezzi G, et al. Avelumab in gastric cancer. Immunotherapy. 2019;11(9):759-68.

245. Kang YK, Boku N, Satoh T, Ryu MH, Chao Y, Kato K, et al. Nivolumab in patients with advanced gastric or gastro-oesophageal junction cancer refractory to, or intolerant of, at least two previous chemotherapy regimens (ONO-4538-12, ATTRAC TION-2): a randomised, double-blind, placebo-controlled, phase 3 trial. Lancet. 2017;390(10111):2461-71.

246. Iwata TN, Ishii C, Ishida S, Ogitani Y, Wada T, Agatsuma T. A HER2-targeting antibody-drug conjugate, trastuzumab deruxtecan (DS-8201a), enhances antitumor immunity in a mouse model. Mol Cancer Ther. 2018;17(7):1494-503.

Publisher's Note Springer Nature remains neutral with regard to jurisdictional claims in published maps and institutional affiliations. 